Farooq A. Kiani • Matthias Hofmann

\title{
Periodic trends and easy estimation of relative stabilities in 11-vertex nido-p-block-heteroboranes and -borates
}

Received: 22 April 2005/ Accepted: 26 July 2005/Published online: 29 October 2005

(C) Springer-Verlag 2005

\begin{abstract}
Density functional theory computations were carried out for 11-vertex nido-p-block-hetero(carba)boranes and -borates containing silicon, germanium, tin, arsenic, antimony, sulfur, selenium and tellurium heteroatoms. A set of quantitative values called "estimated energy penalties" was derived by comparing the energies of two reference structures that differ with respect to one structural feature only. These energy penalties behave additively, i.e., they allow us to reproduce the DFT-computed relative stabilities of 11-vertex nidoheteroboranes in general with good accuracy and to predict the thermodynamic stabilities of unknown structures easily. Energy penalties for neighboring heteroatoms (HetHet and HetHet') decrease down the group and increase along the period (indirectly proportional to covalent radii). Energy penalties for a fiverather than four-coordinate heteroatom, $\left[\mathrm{Het}_{5 \mathrm{k}}(1)\right.$ and $\left.\mathrm{Het}_{5 \mathrm{k}}(2)\right]$, generally, increase down group 14 but decrease down group 16, while there are mixed trends for group 15 heteroatoms. The sum of HetHet' energy penalties results in different but easily predictable openface heteroatom positions in the thermodynamically most stable mixed heterocarbaboranes and -borates with more than two heteroatoms.
\end{abstract}

Keywords Structural features - Structural increments · Energy penalties $\cdot$ Density functional theory $\cdot 11$-Vertex nido-heteroboranes and heteroborates $\cdot 11$-Vertex nido-heterocarbaboranes and heterocarbaborates

Electronic Supplementary Material Supplementary material is available for this article at http://dx.doi.org/10.1007/10.1007/ s00894-005-0037-3 and is accessible for authorized users.

Dedicated to Professor Dr. Paul von Ragué Schleyer on the occasion of his 75 th birthday

F. A. Kiani · M. Hofmann $(\square)$

Anorganisch-Chemisches Institut,

Ruprecht-Karls-Universität Heidelberg,

Im Neuenheimer Feld 270, 69120 Heidelberg, Germany

E-mail: matthias.hofmann@aci.uni-heidelberg.de

\section{Introduction}

The 11-vertex nido-cluster represents the most diverse family of heteroboranes and -borates. Many reactions are known [1-3] to incorporate a hetero-fragment into a smaller nido- or arachno-cluster, leading to 11-vertex nido-heteroboranes. Removal of one vertex from a 12vertex closo-heteroborane cluster also leads to 11-vertex nido-heteroboranes and -borates [2, 4, 5]. Experimentally known 11-vertex nido-heteroborane and -borate clusters include: group 14 heteroatoms, i.e., carbon [6-9], silicon [10-13], germanium [14-17] and tin [6-8, 18-21]; group 15 heteroatoms, i.e., nitrogen, phosphorus [1, 2], arsenic $[5,22-32]$ and antimony [33]; group 16 heteroatoms, i.e., sulfur [34], selenium [35-41] and tellurium [35-37, 42, 53]. Williams' qualitative rules predict isomers with lowcoordinate heteroatoms and separated heteroatoms to be preferred [6,54,55]. While these rules suffice to select the most stable closo-heteroboranes, the presence of additional endo-hydrogen atoms, the large number of isomers and possibly irresolvable conflicts ask for more sophisticated rules to predict the most favorable isomer in the case of nido-clusters.

A set of quantitative rules was presented that reproduced the stability order of 6-vertex nido-carboranes on the basis of 15 structural increments [56]. Disfavoring structural features, e.g., neighboring carbon atoms, were identified and the so-called energy penalties were derived by a statistical fitting procedure. Applying these energy penalties additively, the stability order of isomeric 6-vertex nido-(carba)boranes and -borates can easily be derived by a paper-and-pencil approach. With only nine such fitted quantitative rules, the relative stability order of numerous 11-vertex nido-(carba)boranes and -borates [57] was reproduced successfully. The approach was applied to the 10-vertex nido-(carba)boranes and -borates [58], and to the 11-vertex nido-mixed hetero(carba)boranes and -borates [59] with $\mathrm{H}-\mathrm{C}, \mathrm{P}$, $\mathrm{H}-\mathrm{P}, \mathrm{N}$ and $\mathrm{H}-\mathrm{N}$ heteromoieties. Our work [56-59] quantified Williams' rules $[6,54,55]$ by corresponding 
energy penalties for each heteroatom and introduced some more rules due to open-face hydrogen characteristics of the nido-cluster. These quantitative rules allow us not only to predict the thermodynamically most stable isomer but also to estimate a stability order of various isomers easily [56-59]. Furthermore, these energy penalties successfully elaborate which two heteroatoms are more favorable choices for adjacent positions in the thermodynamically most stable mixed nido-heteroboranes. For example, quantitative rules indicate 7,8,10rather than 7,8,9-, 7,9,10- and 7,9,8-positions for the heteroatoms in nido- $\left[\mathrm{P}_{2} \mathrm{CB}_{8} \mathrm{H}_{9}\right]^{-}$to be thermodynamically most stable [59].

In our previous work [56-59], energy penalties $\left(E_{\text {inc }}\right)$ were determined by statistical fitting to a large number of structures. This procedure gives accurate values but requires extensive computations. Estimated energy penalties, $\left(E_{\text {inc }}{ }^{\prime}\right)$, which are the energy difference of two suitable reference structures differing with respect to one structural feature only, are usually very close to the energy penalties arising from statistical fitting to a large number of isomers [59]. This is to be expected when structural features behave additively. For instance, the estimated energy penalty for adjacent carbon atoms, i.e., the energy difference of $7,8-\mathrm{C}_{2} \mathrm{~B}_{9} \mathrm{H}_{11}^{2-}$ and $7,9-\mathrm{C}_{2} \mathrm{~B}_{9} \mathrm{H}_{11}^{2-}$ is $16.3 \mathrm{kcal} \mathrm{mol}^{-1}$, very close to the statistically fitted value $\left(16.0 \mathrm{kcal} \mathrm{mol}^{-1}\right)$ derived from 20 carboranes [57$59]$. Here, we present the relative stability order $\left(E_{\text {inc }}^{\text {rel }}\right)$ for 11-vertex nido-sila-, germana-, stanna-, arsa-, stiba-, thia-, selena- and tellura(carba)boranes and -borates, phosphathiaboranes and -borates and selenathiaboranes produced by $E_{\text {inc }}{ }^{\prime}$, which are more approximate but easier to determine and are accurate enough for the interpretation of general trends which we wish to investigate in the present study.

The numbering scheme for the 11-vertex nido-cluster is shown in Fig. 1. The apical position is numbered as 1 . The vertices next to the apex (middle belt) are given numbers $2-6$, while the vertices of the open face are numbered from 7 to 11 where 7 is connected to 2 and 3 . There are six cage vertices with connections to five other cluster atoms, $k_{\mathrm{c}}=5$ and five peripheral vertices with $k_{\mathrm{p}}=4$, where, $\mathrm{c}$ and $\mathrm{p}$ denote cage and peripheral vertices, respectively. In the literature, different numbering patterns have been used for mixed heteroboranes.

\section{Computational details}

For all hetero(carba)boranes and -borates except stanna, stiba and tellura(carba)boranes and -borates, geometries were consecutively optimized at B3LYP/3-21G and B3LYP/6-31G(d) using the Gaussian 98 program [60]. The structures presented in this paper are local minima at B3LYP/6-31G(d). Single point energies were computed at B3LYP/6-311+G(d,p). Zero point vibrational energies from B3LYP/6-31G(d) frequency calculations were included to derive the relative energies for all the isomers.
For stanna, stiba and telluraboranes, geometries were optimized at the B3LYP/LANL2DZ level with additional d-polarization functions [61] for $\mathrm{Sn}, \mathrm{Sb}, \mathrm{Te}, \mathrm{B}$ and $\mathrm{C}$ atoms $(\zeta=0.183,0.211,0.237,0.388,0.600$, respectively). Single point energies were determined at B3LYP/ SDD together with p-polarization function for $\mathrm{H}$ $(\zeta=1.000)$ and d-polarization function for $\mathrm{Sn}, \mathrm{Sb}, \mathrm{Te}, \mathrm{B}$ and $C$ [61] along with an sp set of diffuse functions for $\mathrm{Sn}, \mathrm{Sb}, \mathrm{Te}(\zeta=0.0231,0.0259,0.0306$, respectively) [62] as well as for B and $\mathrm{C}(\zeta=0.0315$ and 0.0438 , respectively) [63].

\section{Results and discussion}

Structural features for hetero(carba)boranes and -borates

Different structural features for hetero(carba)boranes and -borates are shown in Fig. 2 and their energy penalties are listed in Table 1. Energy penalties for carbon in Table 1 are statistically fitted values taken from our previous work [57, 59]. For all other heteroatoms, the energy penalties are estimated as the energy difference of two structures that differ with respect to one structural feature only.

\section{$\operatorname{Het}_{5 k}(1)$ and $\operatorname{Het}_{5 k}(2)$}

A heteroatom at a $5 \mathrm{k}$ position (1-6) rather than a $4 \mathrm{k}$ position (7-11) is indicated by the structural feature Het $_{5 \mathrm{k}}$ [57]. The apical position (number 1) differs from positions 2-6: the former has only $5 \mathrm{k}$ neighbors, the latter has two $4 \mathrm{k}$ and three $5 \mathrm{k}$ neighbors. Hence, higher energy penalties are observed for position 1, i.e., $\operatorname{Het}_{5 \mathrm{k}}(1)$, as compared to positions 2 through 6, i.e.,

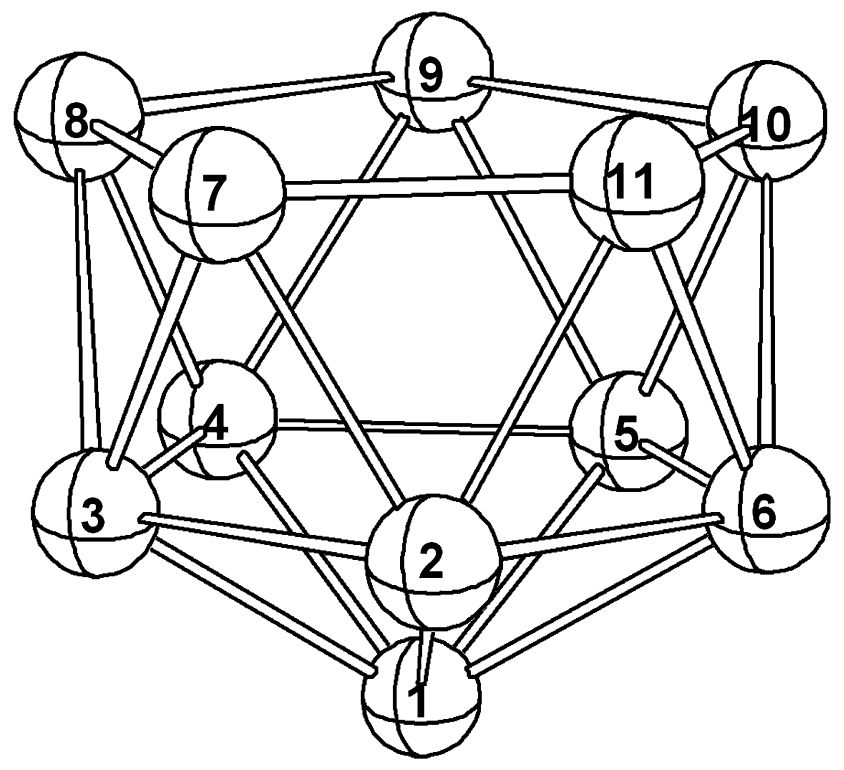

Fig. 1 Numbering scheme for the 11-vertex nido-cluster 
Fig. 2 a A heteroatom (Het) at a $5 \mathrm{k}$ apical position (vertex number 1 , structure $B$ ) or in the middle belt (positions 2 through 6 , structure $C$ ) rather than at the open face (positions 7 through 11, structure $A$ ) represent the structural features $\operatorname{Het}_{5 \mathrm{k}}(1)$ and $\operatorname{Het}_{5 \mathrm{k}}(2)$, respectively. b Heteroatom adjacent $(E)$ rather than heteroatom apart isomer $(D)$ represent the structural feature HetHet', where Het and Het' may be equal or different heteroatoms. $n$ and $n^{\prime}$ are the number of electrons donated by two heteroatoms (Het and Het') c $\mu-H-8,9$ (hydrogen bridge adjacent to heteroatom, $H$ ) rather than $\mu-H-9,10$ (hydrogen bridge far away from heteroatom, $F$ ) in nido-7$\left[\operatorname{HetB}_{10} \mathrm{H}_{11}\right]^{(4-\mathrm{n})-}$, represent the structural feature $\operatorname{Het}(\mathrm{H})$. Hydrogen as an exo-substituent $(G)$ rather than bridged between positions 9 and $10(F)$ produces the structural feature $\mathrm{Het}^{\mathrm{R}}$

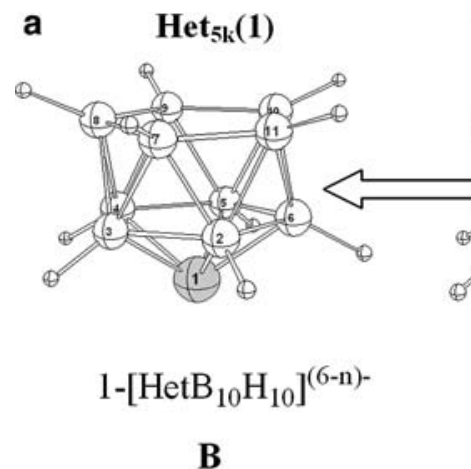

B

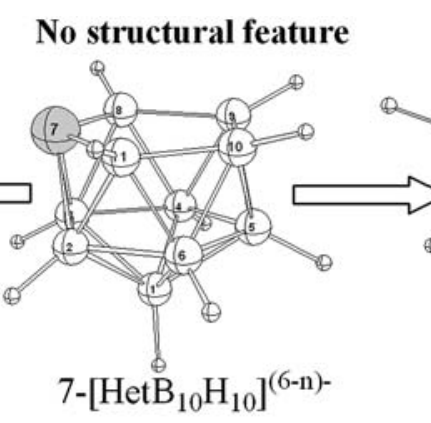

A
Het $_{5 \mathrm{k}}$ (2)

b

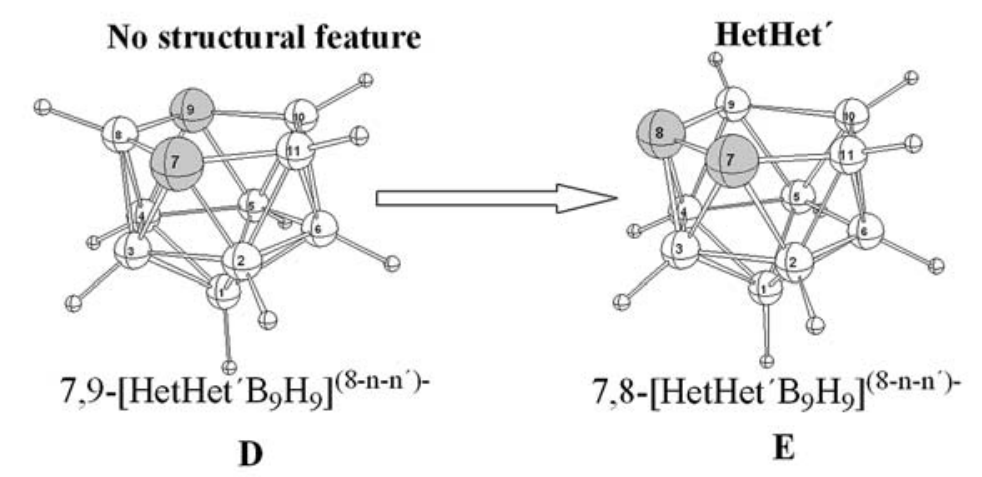

c

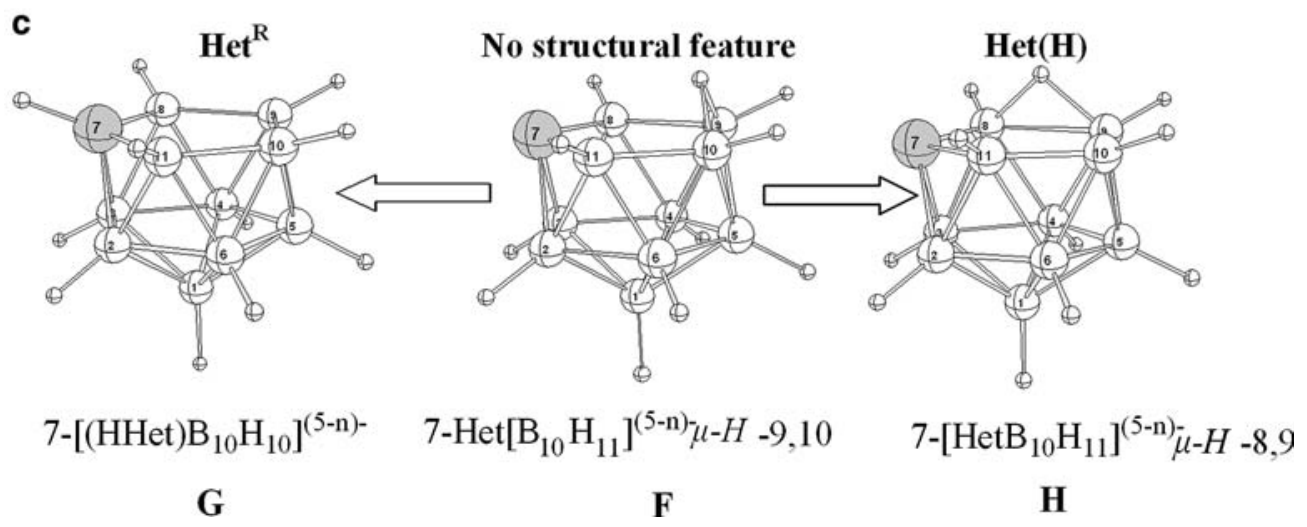

$\mathrm{Het}_{5 \mathrm{k}}(2)$ [57]. Estimated $\mathrm{Het}_{5 \mathrm{k}}(1)$ energy penalties for a given heteroatom were obtained by comparing the 7and 1-isomers of $\left[\mathrm{HetB}_{10} \mathrm{H}_{10}\right]^{(6-\mathrm{n})-}$ and that of $\operatorname{Het}_{5 \mathrm{k}}(2)$ by comparing 7- and 2-isomers of $\left[\mathrm{HetB}_{10} \mathrm{H}_{10}\right]^{(6-\mathrm{n})-}$ (Fig. 2a), where Het $=\mathrm{H}-\mathrm{C}, \mathrm{H}-\mathrm{Si}, \mathrm{N}, \mathrm{H}-\mathrm{N}, \mathrm{P}$ or $\mathrm{H}-\mathrm{P}$ etc. and $n=$ number of electrons donated by a given hetero group. $E_{\text {inc }}{ }^{\prime}\left[\operatorname{Het}_{5 \mathrm{k}}(1)\right]$ and $E_{\mathrm{inc}}{ }^{\prime}\left[\operatorname{Het}_{5 \mathrm{k}}(2)\right]$ for different heteroatoms are listed in Table 1. For the carbon atom at a $5 \mathrm{k}$ position in heterocarbaboranes, the statistically fitted energy penalty of $28.0 \mathrm{kcal} \mathrm{mol}{ }^{-1}$ obtained originally from 11-vertex nido-carboranes will be used [57].

\section{HetHet'}

Heteroatom-apart isomers are generally more favorable than heteroatom-adjacent isomers in heteroboranes and -borates [6, 54-59]. The structural feature HetHet' gives the amount of destabilization caused by two adjacent heteroatoms. For example $7,8-\left[\mathrm{C}_{2} \mathrm{~B}_{8} \mathrm{H}_{10}\right]^{2-}$ with two adjacent carbon atoms (CC) is $16.3 \mathrm{kcal} \mathrm{mol}^{-1}$ less stable than carbon apart 7,9-isomer [57, 59]. The estimated energy penalties for HetHet' were obtained by comparing the 7,8- and 7,9-isomers of $\left[\text { HetHet }^{\prime} \mathrm{B}_{9} \mathrm{H}_{9}\right]^{\left(8-\mathrm{n}-\mathrm{n}^{\prime}\right)-}$ (Fig. 2b), where Het or Het' may be equal or different heteroatoms and $n$ and $n^{\prime}$ are the number of electrons donated by Het and Het'. When Het and Het' $^{\prime}$ are three-electron-donating heteroatoms $\left(\sum n=6\right)$, the structures to be compared are dianions, but they are neutral and monoanionic for two fourelectron-donating heteroatoms $\left(n+n^{\prime}=8\right)$ and one three and one four-electron-donating heteroatom $\left(n+n^{\prime}=7\right)$, respectively. HetHet' energy penalties for two adjacent carbon atoms, CC [57], and two adjacent phosphorus atoms, PP [59], are 16.0 and $10.7 \mathrm{kcal} \mathrm{mol}^{-1}$, respectively. HetHet' energy penalties for $\mathrm{Het}^{\prime}=\mathrm{Het}$ and for $\mathrm{Het}^{\prime}=\mathrm{C}$ are listed in Table 1 . The energy penalties for a heteroatom adjacent to a bare phosphorus atom 
Table 1 Relative trends of energy penalties $\left[\mathrm{kcal} \mathrm{mol}^{-1}\right]$ for different features in 11-vertex nido-hetero(carba)boranes and -borates

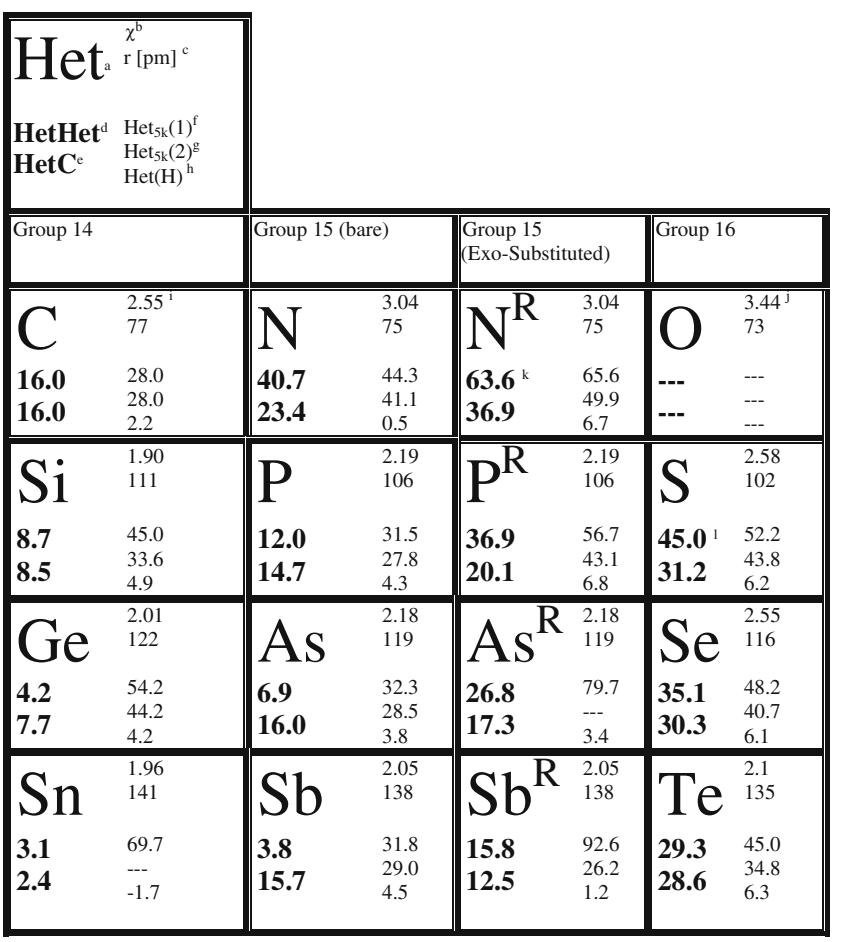

${ }^{\mathrm{a}}$ Heteroatom

${ }^{\mathrm{b}}$ Electronegativity values, see Pauling, L. The Nature of the Chemical Bond. Cornell University Press: Ithaca, New York, 1960

${ }^{\mathrm{c}}$ Covalent radii in pico meter, see Huheey, J.E.; Keiter, E.A.; Keiter, R.L. Inorganic chemistry: Principles of structure and reactivity, 4th edition, HarperCollins, New York, USA, 1993

${ }^{\mathrm{d}}$ Energy penalty for two identical adjacent heteroatoms in the 11-vertex nido-cluster

${ }^{\mathrm{e} E n e r g y ~ p e n a l t y ~ f o r ~ a ~ h e t e r o a t o m ~ a d j a c e n t ~ t o ~ a ~ c a r b o n ~ a t o m ~ i n ~ t h e ~}$ 11 -vertex nido-cluster

${ }^{\mathrm{f}} \mathrm{Het}_{5 \mathrm{k}}(1)$ is the structural feature for a heteroatom at a $5 \mathrm{k}$ apical position (vertex number 1) rather than the ideal $4 \mathrm{k}$ open face positions

${ }^{\mathrm{g}} \mathrm{Het}_{5 \mathrm{k}}(2)$ is the structural feature for a heteroatom at vertices 2 through 6 rather than at the ideal $4 \mathrm{k}$ open face positions

${ }^{\mathrm{h}}$ Structural feature Het $(\mathrm{H})$ denotes the amount of destabilization caused by a heteroatom adjacent to a bridged hydrogen atom

${ }^{i}$ Statistically fitted values taken from ref. 31 . For all other heteroatoms, energy penalties are estimated by comparing two suitable reference structures which differ with respect to one structural feature

${ }^{\mathrm{j}}$ Initial starting 11-vertex nido-oxaborane geometries did not survive geometry optimizations due to the expected very high energy penalties of the oxygen atom

${ }^{\mathrm{k}}$ The $\mathrm{N}^{\mathrm{R}} \mathrm{N}^{\mathrm{R}}$ energy penalty could not be accurately obtained as the structure rearranged. The rough energy penalty derived by fixing N7-B2 and N8-B2 distances to be $1.775 \AA$ was even higher $(76.5$ kcal $\mathrm{mol}^{-1}$ )

${ }^{1}$ The energy penalty for SS (45 kcal mol ${ }^{-1}$ ) also needed to be derived by fixing the $\mathrm{S}(7)-\mathrm{S}(8)$ bond distance to be $2.34 \AA$

(HetP) and to an exo-substituted phosphorus atom $\left(\right.$ HetP $\left.^{\mathrm{R}}\right)$ are listed in Table 2.

Very similar energy penalties were derived for CC (i.e., two adjacent carbon atoms) in carboranes $(16.0 \mathrm{kcal}$ $\left.\mathrm{mol}^{-1}\right)$ [57], phosphacarbaboranes $\left(18.3 \mathrm{kcal} \mathrm{mol}^{-1}\right)$ [59], exo-substituted azacarbaboranes $\left(15.4 \mathrm{kcal} \mathrm{mol}^{-1}\right)$ [59]
Table 2 Energy penalties [kcal mol ${ }^{-1}$ ] for $\operatorname{HetP}^{\mathrm{R}}$ and HetP together with covalent radius of heteroatom (Het)

\begin{tabular}{lll}
\hline HetHet' & $\mathrm{R}_{\mathrm{Het}}[\mathrm{pm}]$ & $E_{\text {inc }}{ }^{\prime}\left[\mathrm{kcal} \mathrm{mol}^{-1}\right]$ \\
\hline $\mathrm{NP}$ & 71 & 18.8 \\
$\mathrm{CP}$ & 77 & 15.1 \\
$\mathrm{PP}$ & 93 & 10.7 \\
$\mathrm{~N}^{\mathrm{R}} \mathrm{P}^{\mathrm{R}}$ & 71 & 42.5 \\
$\mathrm{P}^{\mathrm{R}} \mathrm{P}^{\mathrm{R}}$ & 93 & 36.9 \\
$\mathrm{SP}^{\mathrm{R}}$ & 104 & 38.8 \\
$\mathrm{SeP}^{\mathrm{R}}$ & 117 & 35.8 \\
\hline
\end{tabular}

and thiacarbaboranes $\left(17.7 \mathrm{kcal} \mathrm{mol}^{-1}\right)$. Hence, we use an average value of $17.0 \mathrm{kcal} \mathrm{mol}^{-1}$ for $E_{\text {inc }}[C \mathrm{C}]$ in all heterocarbaboranes considered in this work.

\section{$\operatorname{Het}(H)$}

This structural feature presents the amount of destabilization caused by a heteroatom (Het) adjacent to a hydrogen bridge. Comparing nido-7-[HetB $\left.{ }_{10} \mathrm{H}_{11}\right]^{(5-\mathrm{n})-}$ isomers, $(n=$ number of electrons donated by Het) with $\mu-H-8,9$ and $\mu-H-9,10$ hydrogen positions, directly gives an estimated energy penalty for the structural feature Het(H) (Fig. 2c). This structural feature has a relatively small destabilizing effect. For example, the energy penalty for $\mathrm{C}(\mathrm{H})$ was determined to be $2.2 \mathrm{kcal} \mathrm{mol}^{-1}$ for carboranes [57]. The energy penalties of other heteroatoms adjacent to a hydrogen bridge are listed in Table 1. The largest $\operatorname{Het}(\mathrm{H})$ energy penalty $(9.4 \mathrm{kcal}$ $\mathrm{mol}^{-1}$ ) is observed for the four-electron-donating $\mathrm{P}^{\mathrm{R}}$ heterogroup, while tin has the smallest (even negative) energy penalty $E_{\text {inc }}{ }^{\prime}[\mathrm{Sn}(\mathrm{H})]=-1.7 \mathrm{kcal} \mathrm{mol}^{-1}$. It is the only negative energy penalty observed for any heteroatom structural feature in 11-vertex nido-heteroboranes.

\section{$\mathrm{Het}^{R}$}

This structural feature allows to compare bare (threeelectron donating) and exo-substituted (four-electron donating) group 14 heteroatoms. nido-7-[HetB $\left.{ }_{10} \mathrm{H}_{11}\right]^{2-}$ $(\mu-H-9,10)$ and nido-7-[(HHet) $\left.\mathrm{B}_{10} \mathrm{H}_{10}\right]^{2-}$ (Fig. $\left.2 \mathrm{c}\right)$ give a direct estimate of the energy penalty of $\mathrm{Het}^{\mathrm{R}}$ for group 15 heteroatoms. Generally, three-electron-donating nitrogen and phosphorus atoms ( $\mathrm{N}$ and $\mathrm{P}$ ) have smaller energy penalties as compared to four electron donating exo-substituted nitrogen and phosphorus $\left(\mathrm{N}^{\mathrm{R}}\right.$ and $\left.\mathrm{P}^{\mathrm{R}}\right)$ atoms [59]. The same is true for bare arsenic (As) and antimony $(\mathrm{Sb})$ atoms in the 11-vertex nido-cluster which have generally smaller energy penalties as compared to exo-substituted arsenic $\left(\mathrm{As}^{\mathrm{R}}\right)$ and antimony $\left(\mathrm{Sb}^{\mathrm{R}}\right)$ atoms (see Table 1).

Energy penalties as periodic properties of heteroatoms in 11-vertex nido-clusters

In this section, the general trends of $\operatorname{HetHet}^{\prime}, \operatorname{Het}_{5 \mathrm{k}}(1)$ and $\operatorname{Het}_{5 \mathrm{k}}(2)$ energy penalties will be discussed. 
HetHet and HetC energy penalties decrease along group $14(\mathrm{C} \rightarrow \mathrm{Sn}), 15(\mathrm{~N} \rightarrow \mathrm{Sb})$ and $16(\mathrm{~S} \rightarrow \mathrm{Te})$ and increase along the periods $(\mathrm{C} \rightarrow \mathrm{N}, \mathrm{Si} \rightarrow \mathrm{S}, \mathrm{Ge}$ $\rightarrow \mathrm{Se}, \mathrm{Sn} \rightarrow \mathrm{Te}$, see Table 1). The magnitude of energy penalties depends largely upon the extent of electron localization, which is determined primarily by the number of electrons donated by a heteroatom and secondarily by the electronegativity of the heteroatom. All the heteroatoms in Table 1 formally donate more than two electrons (two electrons are donated by a $\mathrm{BH}$ vertex) to the total of 26 skeletal electrons required in an 11-vertex nido-cluster and hence cause stronger electron localization as compared to a $\mathrm{BH}$ vertex. Two adjacent heteroatoms result in a larger degree of electron localization on two adjacent vertices and hence a positive HetHet energy penalty. This HetHet energy penalty is more positive for three-electron-donating group 15 heteroatoms as compared to the three-electron-donating group 14 heteroatoms. This is due to the larger electronegativity of three-electron-donating group $15 \mathrm{mem}$ bers. Four-electron-donating group 15 members have even higher electron localization due to four rather than three electrons localized at one vertex. Group 16 heteroatoms have even higher energy penalties as compared to group 15 heteroatoms due to larger electronegativity of the group 15 heteroatoms. It is interesting to note that neighboring $\mathrm{NH}$ groups have such a large destabilizing effect that the energy penalty could only be estimated by fixing the $\mathrm{N}(7)-\mathrm{B}(2)$ and $\mathrm{N}(8)-\mathrm{B} 2$ distances as the cluster shape was destroyed upon free geometry optimization [59]. Considering the general trends, the energy penalties for oxygen should be the largest but none of the five structural features for 11-vertex nido-oxaboranes could be determined as none of the oxaborane starting geometries optimized to a nido-11-vertex cluster geometry. Among the heteroatoms in Table 1, oxygen is the only one for which no experimentally known 11-vertex nido-heteroborane exists. The smallest HetHet energy penalty $\left(3.1 \mathrm{kcal} \mathrm{mol}^{-1}\right)$ is found for tin (on the left bottom of Table 1).

Geometric consequences also seem to be important. Incorporation of one large heteroatom requires geometric distortion of the cluster. Incorporating another large heteroatom next to the first enhances the geometric distortion but to a lesser extent as compared to placing it at a yet undistorted site. Although this effect is overruled by the opposing electronic effects, it considerably reduces the energy penalties for two adjacent larger heteroatoms. When there is a significant electronegativity difference between boron and the heteroatoms, the electronic effect dominates. However, when the electronegativity of the heteroatom is very close to that of boron, the relative position of hetero-groups does not influence the electronic situation much and the geometric consequences are important.

Figure 3 shows such general trends for HetHet' and HetC energy penalties, which are indirectly proportional to the covalent radii (directly proportional to electronegativity) within one group. Table 2 also shows very similar effects for $\operatorname{HetP}^{\mathrm{R}}$ and HetP energy penalties, where one heteroatom is a phosphorus atom.

Energy penalties for $\operatorname{Het}_{5 \mathrm{k}}(1)$ and $\mathrm{Het}_{5 \mathrm{k}}(2)$ increase down group 14 but decrease down group 16. For both three- as well as four-electron-donating heteroatoms in group 15, however, they show mixed trends (Fig. 4).
Fig. 3 Covalent radii, HetHet and HetC energy penalties for group 14, group 15 and group 16 heteroatoms. HetHet and $\mathrm{HetC}$ energy penalties for heteroatoms increase with decrease in covalent radii

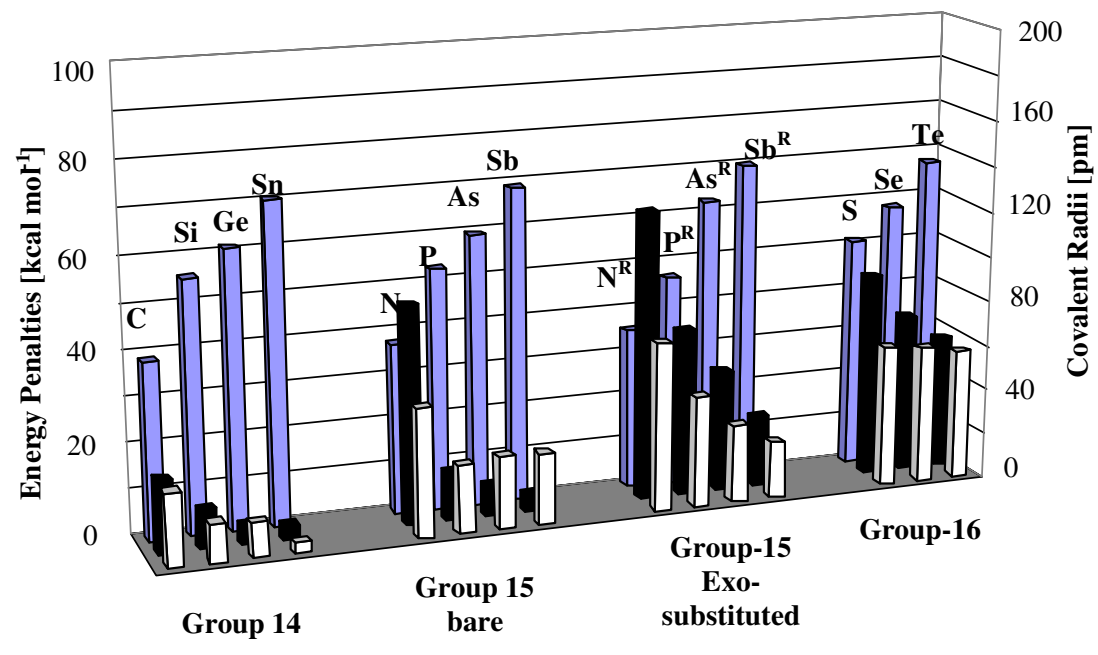

Covalent Radii [pm]

$\mathrm{E}_{\text {inc }}{ }^{\prime}$ HetHet $\left[\mathrm{kcal} \mathrm{mol}^{-1}\right]$

$\mathrm{E}_{\mathrm{inc}}{ }^{\prime} \mathrm{HetC}\left[\mathrm{kcal} \mathrm{mol}^{-1}\right]$ 
Fig. $4 \operatorname{Het}_{5 \mathrm{k}}(1)$ and $\mathrm{Het}_{5 \mathrm{k}}(2)$ energy penalties for group 14 heteroatoms decrease with decreasing covalent radii but increase for group 16 heteroatoms. Group 15 heteroatoms have mixed trends

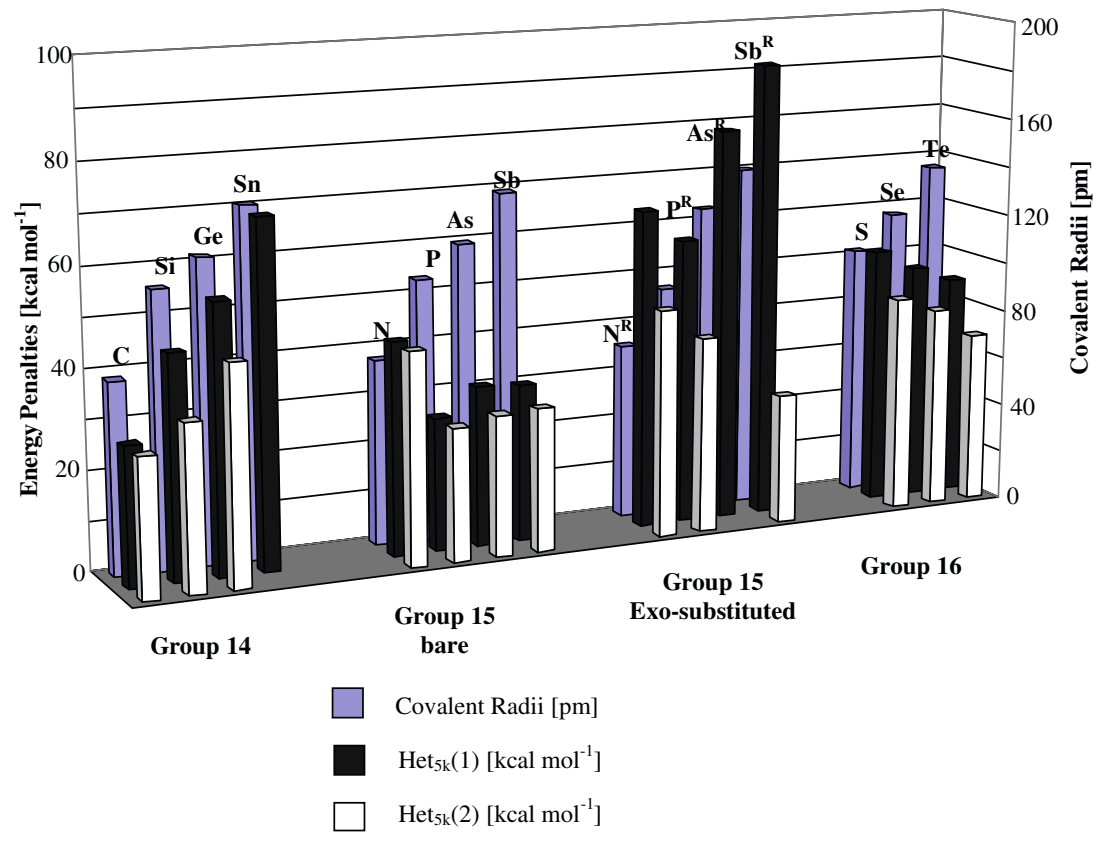

The importance of geometric consequences also becomes clear by the pronounced preference for openface positions for larger heteroatoms. Larger heteroatoms have much larger $\operatorname{Het}_{5 \mathrm{k}}(1)$ and $\operatorname{Het}_{5 \mathrm{k}}(2)$ energy penalties. The larger heteroatoms cause more geometric distortion when connected to five cage vertices (at apical position or in the middle belt), and hence larger energy penalties as compared to the smaller heteroatoms which are closer to a $\mathrm{BH}$ vertex in size. In the open face, larger heteroatoms are

Table 3 Estimated energy penalties $\left(E_{\text {inc }}{ }^{\prime}\right)$, estimated relative energies $\left(E_{\text {inc }}^{\text {rel }}\right)$ and computed relative energies for thia(carba)boranes and -borates. All values are in $\mathrm{kcal} \mathrm{mol}^{-1}$

\begin{tabular}{|c|c|c|c|c|c|c|c|c|c|c|c|c|c|}
\hline & Compound & $\mu-H-$ & $\begin{array}{l}\mathrm{C}_{5 \mathrm{k}} \\
28.0\end{array}$ & $\begin{array}{l}\mathrm{C}(\mathrm{H}) \\
2.1\end{array}$ & $\begin{array}{l}\mathrm{CC} \\
17.0\end{array}$ & $\begin{array}{l}\mathrm{S}_{5 \mathrm{k}}(1)^{\prime} \\
52.2\end{array}$ & $\begin{array}{l}\mathrm{S}_{5 \mathrm{k}}(2)^{\prime} \\
43.8\end{array}$ & $\begin{array}{l}\mathrm{S}(\mathrm{H})^{\prime} \\
6.2\end{array}$ & $\begin{array}{l}\mathrm{SC}^{\prime} \\
31.2\end{array}$ & $\sum E_{\text {inc }}{ }^{\prime}$ & $E_{\text {inc }}^{\text {rel }}$ & $E_{\text {calc }}$ & $\Delta E^{\prime}$ \\
\hline $\mathbf{A} \mathbf{A}^{\mathrm{a}}$ & 7- $\mathrm{SB}_{10} \mathrm{H}_{12}$ & 8,$9 ; 9,10$ & & & & & & 2 & & 12.4 & 0.0 & 0.0 & 0.0 \\
\hline $\mathbf{A B}$ & $2-\mathrm{SB}_{10} \mathrm{H}_{12}$ & 7,$8 ; 9,10$ & & & & & 1 & 1 & & 50.0 & 37.6 & 39.8 & -2.2 \\
\hline $\mathrm{AC}$ & $1-\mathrm{SB}_{10} \mathrm{H}_{12}$ & 7,$8 ; 9,10$ & & & & 1 & & & & 52.2 & 39.8 & 43.8 & -4.0 \\
\hline $\mathbf{B A}^{\mathrm{a}}$ & 7- $\mathrm{SB}_{10} \mathrm{H}_{11}^{1-}$ & 9,10 & & & & & & & & 0.0 & 0.0 & 0.0 & 0.0 \\
\hline $\mathbf{B B}^{\mathrm{a}}$ & 7-SB ${ }_{10} \mathrm{H}_{11}^{1-}$ & 8,9 & & & & & & 1 & & 6.2 & 6.2 & 6.2 & 0.0 \\
\hline BC & $2-\mathrm{SB}_{10} \mathrm{H}_{11}^{1-}$ & 8,9 & & & & & 1 & & & 43.8 & 43.8 & 44.3 & -0.5 \\
\hline $\mathbf{C A}^{\mathrm{b}}$ & 7- $\mathrm{SB}_{10} \mathrm{H}_{10}^{2-}$ & - & & & & & & & & 0.0 & 0.0 & 0.0 & 0.0 \\
\hline CB & $2-\mathrm{SB}_{10} \mathrm{H}_{10}^{2-}$ & - & & & & & 1 & & & 43.8 & 43.8 & 43.8 & 0.0 \\
\hline $\mathrm{CC}$ & $1-\mathrm{SB}_{10} \mathrm{H}_{10}^{2-}$ & - & & & & 1 & & & & 52.2 & 52.2 & 52.2 & 0.0 \\
\hline $\mathbf{D A}^{\mathrm{a}}$ & $7,9-\mathrm{S}_{2} \mathrm{~B}_{9} \mathrm{H}_{9}$ & - & & & & & & & & 0.0 & 0.0 & 0.0 & 0.0 \\
\hline DB & $1,7-\mathrm{S}_{2} \mathrm{~B}_{9} \mathrm{H}_{9}$ & - & & & & 1 & & & & 52.2 & 52.2 & 55.5 & -3.3 \\
\hline $\mathbf{E A}^{\mathrm{a}}$ & 7,9-9-SB ${ }_{9} \mathrm{H}_{11}$ & 10,11 & & 1 & & & & 1 & & 8.3 & 0.0 & 0.0 & 0.0 \\
\hline EB & $7,8-\mathrm{SCB}_{9} \mathrm{H}_{11}$ & 9,10 & & 1 & & & & & 1 & 33.3 & 25.0 & 25.6 & -0.6 \\
\hline EC & $7,8-\mathrm{SCB}_{9} \mathrm{H}_{11}$ & 10,11 & & & & & & 1 & 1 & 37.4 & 29.1 & 27.9 & 1.2 \\
\hline ED & $2,8-\mathrm{SCB}_{9} \mathrm{H}_{11}$ & 9,10 & & 1 & & & 1 & & & 45.9 & 37.6 & 35.0 & 2.6 \\
\hline $\mathbf{F A}^{\mathrm{a}}$ & 7,9-SCB ${ }_{9} \mathrm{H}_{10}^{1-}$ & - & & & & & & & & 0.0 & 0.0 & 0.0 & 0.0 \\
\hline FB & $7,8-\mathrm{SCB}_{9} \mathrm{H}_{10}^{1-}$ & - & & & & & & & 1 & 31.2 & 31.2 & 31.2 & 0.0 \\
\hline FC & 7,1-SCB ${ }_{9} \mathrm{H}_{10}^{1-}$ & - & 1 & & & & & & & 28.0 & 28.0 & 33.3 & -5.3 \\
\hline FD & $1,7-\mathrm{SCB}_{9} \mathrm{H}_{10}^{1-}$ & - & & & & 1 & & & & 52.2 & 52.2 & 54.4 & -2.2 \\
\hline $\mathbf{G A}^{\mathrm{a}}$ & $7,9,10-\mathrm{SC}_{2} \mathrm{~B}_{8} \mathrm{H}_{10}$ & - & & & 1 & & & & & 17.0 & 0.0 & 0.0 & 0.0 \\
\hline $\mathbf{G B}^{\mathrm{a}}$ & $7,8,10-\mathrm{SC}_{2} \mathrm{~B}_{8} \mathrm{H}_{10}$ & - & & & & & & & 1 & 31.2 & 14.2 & 13.1 & 1.1 \\
\hline $\mathbf{G C}^{\mathrm{c}}$ & $8,2,10-\mathrm{SC}_{2} \mathrm{~B}_{8} \mathrm{H}_{10}$ & - & 1 & & & & & & & 28.0 & 11.0 & 13.6 & -2.6 \\
\hline $\mathbf{G D}^{\mathrm{c}}$ & $7,1,9-\mathrm{SC}_{2} \mathrm{~B}_{8} \mathrm{H}_{10}$ & - & 1 & & & & & & & 28.0 & 11.0 & 17.5 & -6.5 \\
\hline $\mathbf{G E}^{\mathrm{a}}$ & $7,8,9-\mathrm{SC}_{2} \mathrm{~B}_{8} \mathrm{H}_{10}$ & - & & & 1 & & & & 1 & 48.2 & 31.2 & 32.9 & -1.7 \\
\hline GF & $7,8,11-\mathrm{SC}_{2} \mathrm{~B}_{8} \mathrm{H}_{10}$ & - & & & & & & & 2 & 62.4 & 45.4 & 48.8 & -3.4 \\
\hline
\end{tabular}

${ }^{a}$ Experimentally known isomers

${ }^{b}$ Only metal derivatives are experimentally known

${ }^{\mathrm{c}}$ Strong candidates 
Fig. 5 Most stable thia(carba)borane and -borate represent boron, carbon and sulfur atoms, respectively. AA, BA,

DA-GA are experimentally known. Metal complexes of $\mathbf{C A}$ are also experimentally known isomers. White, black and pink balls
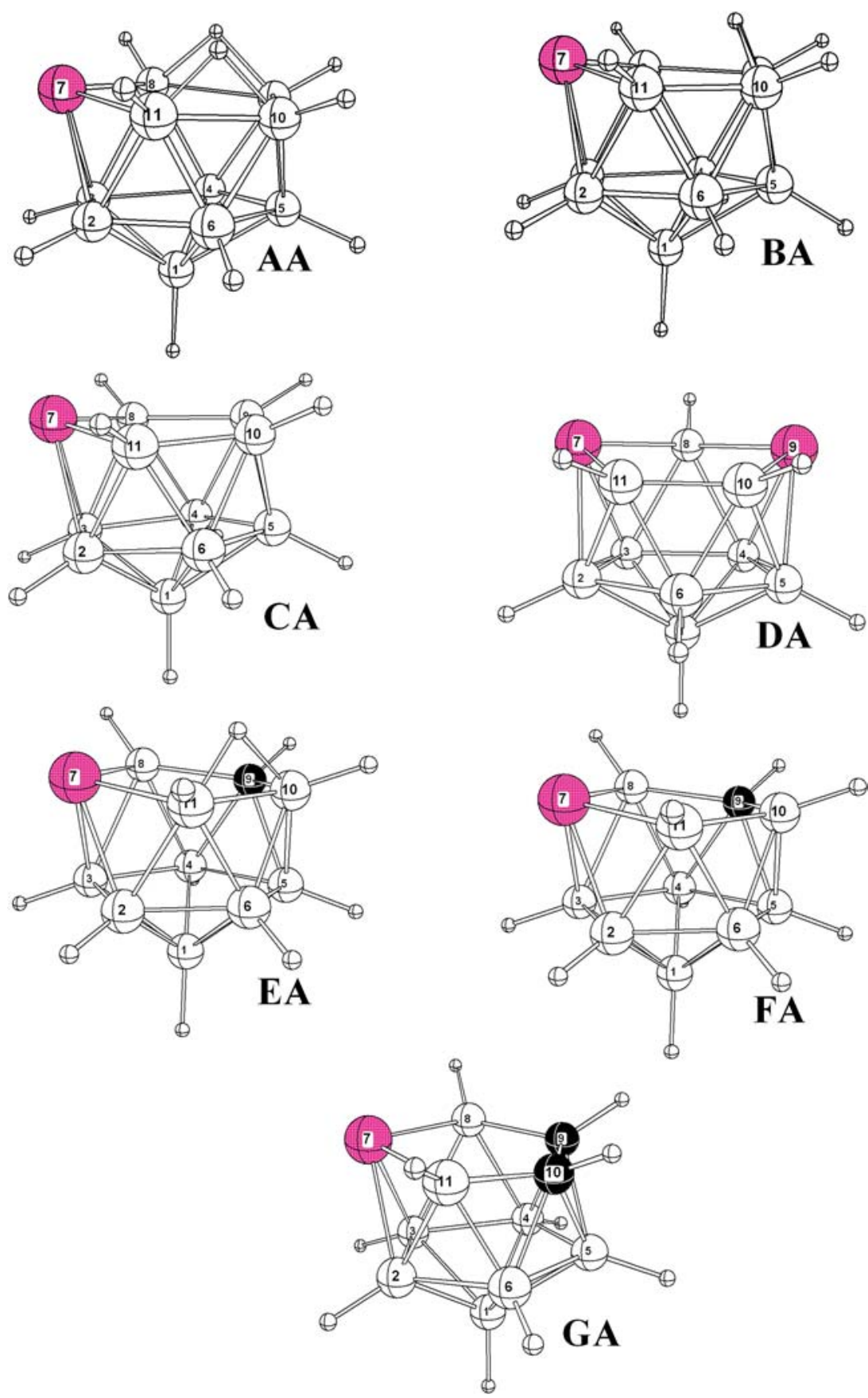

connected to four cluster vertices and hence are more suitable.

The structural feature $\operatorname{Het}(\mathrm{H})$ has very similar energy penalties for four-electron-donating group 16 heteroatoms ( $\mathrm{S}$, Se and Te have energy penalties of $6.2,6.1$ and $6.3 \mathrm{kcal} \mathrm{mol}^{-1}$, respectively), however, $\mathrm{Het}(\mathrm{H})$ energy penalties do not follow any specific general trend for group 14 and -15 heteroatoms. Moreover, Het $(\mathrm{H})$ energy penalties have a small disfavoring effect $\left(\sim 5 \mathrm{kcal} \mathrm{mol}^{-1}\right.$ in many cases) and can be considered as a fine-tuning increment for two structural isomers differing with respect to open face hydrogen positions only.
Comparisons of the estimated relative stabilities $\left(E_{\text {inc }}^{\text {rel }}\right)$ derived from estimated energy penalties $\left(E_{\text {inc }}{ }^{\prime}\right)$ with DFT computed values $\left(E_{\text {calc }}\right)$ for the 11-vertex nido-hetero(carba)boranes and -borates

Estimated $\left(E_{\text {inc }}{ }^{\prime}\right)$ and statistically fitted $\left(E_{\text {inc }}\right)$ energy penalties as well as $E_{\text {inc }}^{\text {rel }}$ were reported for 11-vertex nido(carba)boranes and -borates, phospha(carba)boranes and -borates, and aza(carba)boranes and -borates [59]. In this section, the estimated relative stabilities $\left(E_{\text {inc }}^{\text {rel }}\right)$ are compared with the DFT-computed relative energies $\left(E_{\text {calc }}\right)$ for thia(carba)boranes and -borates, phosphathiaboranes and -borates, selena-, and tellura(carba)boranes 
and -borates, and selenathiaboranes and -borates. $\Delta E^{\prime}$ is the difference between $E_{\text {inc }}^{\text {rel }}$ and $E_{\text {calc }}$.

\section{Thia(carba)boranes and-borates}

Twenty-five isomers of thia(carba)boranes and -borates from nido- $\mathrm{SB}_{10} \mathrm{H}_{12}$ to nido- $\mathrm{SC}_{2} \mathrm{~B}_{8} \mathrm{H}_{10}$ are considered in this study. The estimated energy penalties for $\mathrm{S}_{5 \mathrm{k}}(1)$, $\mathrm{S}_{5 \mathrm{k}}(2), \mathrm{SS}, \mathrm{SC}, \mathrm{CC}$ and $\mathrm{S}(\mathrm{H})$ were obtained as explained in the Structural features for hetero(carba)boranes and -borates section. A total of nine 11-vertex nidothia(carba)borane and -borate clusters is experimentally known (labeled by "a" in Table 3, also see Fig. 5). Metal complexes of nido- $\left[\mathrm{SB}_{10} \mathrm{H}_{10}\right]^{2-}(\mathbf{C A})$ were also reported [64-67]. Two experimentally unknown $\mathrm{SC}_{2} \mathrm{~B}_{8} \mathrm{H}_{10}$ isomers, GC and GD (see Table 3) are predicted as strong candidates for synthesis because of their competitive thermodynamic stabilities.

The experimentally known [3, 34, 68] most stable nido- $\mathrm{SB}_{10} \mathrm{H}_{12}$ isomer, i.e., nido-7- $\mathrm{SB}_{10} \mathrm{H}_{12}$ (AA) has a sulfur atom at the open face with two bridged hydrogen atoms adjacent to the sulfur atom (structural feature $\mathrm{S}(\mathrm{H})$, twice). Both $E_{\text {inc }}^{\text {rel }}$ and $E_{\text {calc }}$ have very similar relative energy values for $\mathbf{A A}$ (nido-2- $\mathrm{SB}_{10} \mathrm{H}_{12}$ ), $\mathbf{A B}$ (nido-2$\mathrm{SB}_{10} \mathrm{H}_{12}$ ) and $\mathbf{A C}$ (nido-1-SB ${ }_{10} \mathrm{H}_{12}$ ) (Table 3).

One extra hydrogen atom in nido-7-[ $\left[\mathrm{SB}_{10} \mathrm{H}_{11}\right]^{-}$(BA) [3] bridges positions 9 and 10, resulting in no disfavoring structural feature but is adjacent to the sulfur atom in isomer $\mathbf{B B}$, resulting in $E_{\text {inc }}{ }^{\prime}[\mathrm{S}(\mathrm{H})]=6.2 \mathrm{kcal} \mathrm{mol}^{-1}$. BC, i.e., nido-2- $\left[\mathrm{SB}_{10} \mathrm{H}_{11}\right]^{-}$has a sulfur atom at position number $2\left(E_{\text {inc }}{ }^{\prime}\left[\mathrm{S}_{5 \mathrm{k}}(2)\right]=43.8 \mathrm{kcal} \mathrm{mol}^{-1}\right)$ and hence the structure is higher in energy than both $\mathbf{B A}$ and $\mathbf{B B}$.

The absence of hydrogen bridges in nido- $\left[\mathrm{SB}_{10} \mathrm{H}_{10}\right]^{2-}$ results in only three possible isomers, i.e., nido-7$\left[\mathrm{SB}_{10} \mathrm{H}_{10}\right]^{2-}(\mathbf{C A})$, nido-2- $\left[\mathrm{SB}_{10} \mathrm{H}_{10}\right]^{2-}(\mathbf{C B})$ and nido-1$\left[\mathrm{SB}_{10} \mathrm{H}_{10}\right]^{2-}(\mathbf{C C})$, used to derive $E_{\mathrm{inc}}{ }^{\prime}\left[\mathrm{S}_{5 \mathrm{k}}(2)\right]=$ $43.8 \mathrm{kcal} \mathrm{mol}^{-1}$ and $E_{\text {inc }}{ }^{\prime}\left[\mathrm{S}_{5 \mathrm{k}}(1)\right]=52.2 \mathrm{kcal} \mathrm{mol}^{-1}$.

The experimentally known [69] nido-7,9- $\mathrm{S}_{2} \mathrm{~B}_{9} \mathrm{H}_{9}$ (DA) is the most stable isomer as it lacks any structural feature. None of the dithiaborane starting geometries with two adjacent sulfur atoms optimized successfully but converged to rearranged structures. However, a rough estimate for the SS feature was obtained by fixing the $\mathrm{S}(7)-\mathrm{S}(8)$ distance in $7,8-\mathrm{S}_{2} \mathrm{~B}_{9} \mathrm{H}_{9}$ to be $2.34 \AA$ ( $45.5 \mathrm{kcal}$ $\mathrm{mol}^{-1}$ ). Obviously, the SS feature, like $\mathrm{N}^{\mathrm{R}} \mathrm{N}^{\mathrm{R}}$ [59], is incompatible with the nido-11-vertex cluster due to too large destabilization.

nido-7,9-SCB ${ }_{9} \mathrm{H}_{11}$ with $\mu-H-10,11$ (EA) [70], the most stable $\mathrm{SCB}_{9} \mathrm{H}_{11}$ isomer, has non-adjacent carbon and sulfur atoms. Isomers EB through ED are at least $25 \mathrm{kcal} \mathrm{mol}^{-1}$ less stable than EA. A similar profound preference is found for the heteroatom apart nido-7,9isomer (FA) [70] among $\left[\mathrm{SCB}_{9} \mathrm{H}_{10}\right]^{-}$structures.

The experimentally known nido-7,9,10- $\mathrm{SC}_{2} \mathrm{~B}_{8} \mathrm{H}_{10}$ (GA) [3] is the most stable of the seven computed isomers. nido-7,8,9- $\mathrm{SC}_{2} \mathrm{~B}_{8} \mathrm{H}_{10}$ (GE) [3] and nido-7,8,10$\mathrm{SC}_{2} \mathrm{~B}_{8} \mathrm{H}_{10}(\mathbf{G B})$ [3] with $E_{\text {calc }}=32.9$ and $14.2 \mathrm{kcal} \mathrm{mol}^{-1}$, respectively are also experimentally known. 8,2,10-(GC) and 7,1,9- $\mathrm{SC}_{2} \mathrm{~B}_{8} \mathrm{H}_{10}(\mathbf{G D})$ are thermodynamically more stable than 7,8,9-SC $\mathrm{SC}_{2} \mathrm{~B}_{8} \mathrm{H}_{10}$ (GE) [3], but are still experimentally unknown.

\section{Phosphathiaboranes and-borates}

The relative stabilities as determined from DFT computations and from structural increments for a few phosphathiaboranes are compared in Table 4. $\left[\mathrm{PSB}_{9} \mathrm{H}_{9}\right]^{-}$structures lack extra hydrogen atoms and possess bare-phosphorus atom/s only. For nido$\mathrm{PSB}_{9} \mathrm{H}_{10}$, however, both bare and exo-substituted phosphorus atoms are considered. The energy penalties derived for a phosphorus atom in phospha(carba)boranes and -borates [59] and for a sulfur atom in thia(carba)boranes and -borates (this paper) along with energy penalties for PS (derived by comparing nido-7,9$\left[\mathrm{PSB}_{9} \mathrm{H}_{9}\right]^{-}$with nido-7,8-[$\left[\mathrm{PSB}_{9} \mathrm{H}_{9}\right]^{-}$) and $\mathrm{P}^{\mathrm{R}} \mathrm{S}$ (derived by comparing nido-7,9-( $\mathrm{PH}) \mathrm{SB}_{9} \mathrm{H}_{9}$ with nido-7,8(PH) $\mathrm{SB}_{9} \mathrm{H}_{9}$ can be used to estimate the relative stabilities of phosphathiaboranes. The estimated relative energies of four nido- $\mathrm{PSB}_{9} \mathrm{H}_{10}$ isomers (i.e., HA-HD that differ in more than one feature) were found to be in good agreement with the relative energies computed at B3LYP/6-311 + G(d,p)//B3LYP/6-31G(d) (see Table 4, HA-HD). 7,9- $\mathrm{PSB}_{9} \mathrm{H}_{10} \mu-H-10,11$ (HA) with the structural features $\mathrm{P}(\mathrm{H})$ and $\mathrm{S}(\mathrm{H})$ has the least $\sum E_{\text {inc }}{ }^{\prime}, E_{\text {inc }}^{\text {rel }}$ and $E_{\text {calc }}$ values but is still experimentally unknown. nido-7,9- $\mathrm{PSB}_{9} \mathrm{H}_{10}$ with an exo-substituted phosphorus atom $(\mathbf{H B})$ is computed to be $3.4 \mathrm{kcal} \mathrm{mol}^{-1}$ higher in

Table 4 Estimated energy penalties $\left(E_{\mathrm{inc}}{ }^{\prime}\right)$, estimated relative energies $\left(E_{\mathrm{inc}}^{\mathrm{rel}}\right)$ for phosphathiaboranes. DFT computed relative energies are also reported for HA to HD. All values are in $\mathrm{kcal} \mathrm{mol}^{-1}$

\begin{tabular}{|c|c|c|c|c|c|c|c|c|c|c|c|}
\hline & Compound & $\mu-H-$ & $\begin{array}{l}\mathrm{P}(\mathrm{H}) \\
2.2\end{array}$ & $\begin{array}{l}\mathrm{P}^{\mathrm{R}} \\
13.3\end{array}$ & $\begin{array}{l}\mathrm{S}(\mathrm{H})^{\prime} \\
6.1\end{array}$ & $\begin{array}{l}\text { PS' }^{\prime} \\
21.4\end{array}$ & $\begin{array}{l}\mathrm{P}^{\mathrm{R}} \mathrm{S}^{\prime} \\
38.8\end{array}$ & $\sum E_{\mathrm{inc}}{ }^{\prime}$ & $E_{\text {inc }}^{\text {rel, }}$ & $E_{\text {calc }}$ & $\Delta E^{\prime}$ \\
\hline $\mathbf{H A}^{\mathrm{a}}$ & 7,9-PSB ${ }_{9} \mathrm{H}_{10}$ & 10,11 & 1 & & 1 & & & 8.3 & 0.0 & 0.0 & 0.0 \\
\hline $\mathbf{H B}^{\mathrm{b}}$ & $7,9-(\mathrm{HP}) \mathrm{SB}_{9} \mathrm{H}_{10}$ & & & 1 & & & & 13.3 & 5.0 & 3.4 & 1.6 \\
\hline HC & 7,8-PSB ${ }_{9} \mathrm{H}_{10}$ & 10,11 & 1 & & & 1 & & 23.6 & 15.3 & 13.8 & 1.5 \\
\hline HD & 7,8 -(HP) $\mathrm{SB}_{9} \mathrm{H}_{10}$ & & & 1 & & & 1 & 52.1 & 43.8 & 42.2 & 1.6 \\
\hline IA & 7,9- $\mathrm{PSB}_{9} \mathrm{H}_{9}^{-}$ & & & & & & & 0.0 & 0.0 & 0.0 & 0.0 \\
\hline IB & 7,8-PSB ${ }_{9} \mathrm{H}_{9}^{-}$ & & & & & 1 & & 21.4 & 21.4 & 21.4 & 0.0 \\
\hline
\end{tabular}

${ }^{\text {a }}$ Strong candidate for synthesis

b7-Ph-HB, i.e., 7-Ph derivative of 7,9- $\mathrm{PSB}_{9} \mathrm{H}_{10}$ is experimentally known 
Table 5 Estimated energy penalties $\left(E_{\text {inc }}{ }^{\prime}\right)$, estimated relative energies $\left(E_{\text {inc }}^{\text {rel }}\right)$ for selenaboranes and -borates. DFT computed relative energies are also reported for some structures. All values are in $\mathrm{kcal} \mathrm{mol} \mathrm{m}^{-1}$

\begin{tabular}{|c|c|c|c|c|c|c|c|c|c|c|}
\hline & Compound & $\mu-H-$ & $\begin{array}{l}\operatorname{Se}_{5 \mathrm{k}}(1)^{\prime} \\
48.2\end{array}$ & $\begin{array}{l}\operatorname{Se}_{5 \mathrm{k}}(2)^{\prime} \\
40.7\end{array}$ & $\begin{array}{l}\mathrm{Se}(\mathrm{H})^{\prime} \\
6.1\end{array}$ & $\begin{array}{l}\mathrm{SeSe}^{\prime} \\
35.1\end{array}$ & $\sum E_{\mathrm{inc}}{ }^{\prime}$ & $E_{\text {inc }}^{\mathrm{rel},}$ & $E_{\text {calc }}$ & $\Delta E^{\prime}$ \\
\hline $\mathbf{J} \mathbf{A}^{\mathrm{a}}$ & 7-SeB ${ }_{10} \mathrm{H}_{12}$ & 8,$9 ; 10,11$ & & & 2 & & 12.2 & 0.0 & 0.0 & 0.0 \\
\hline JB & $2-\mathrm{SeB}_{10} \mathrm{H}_{12}$ & 7,$8 ; 9,10$ & & 1 & 1 & & 46.8 & 34.6 & 39.5 & -4.9 \\
\hline $\mathbf{K A}^{\mathrm{a}}$ & $7-\mathrm{SeB}_{10} \mathrm{H}_{11}^{1-}$ & 9,10 & & & & & 0.0 & 0.0 & 0.0 & 0.0 \\
\hline KB & $7-\mathrm{SeB}_{10} \mathrm{H}_{11}^{1-}$ & 8,9 & & & 1 & & 6.1 & 6.1 & 6.1 & 0.0 \\
\hline KC & $1-\mathrm{SeB}_{10} \mathrm{H}_{11-}^{\mathrm{i}-}$ & 7,8 & 1 & & & & 48.2 & 48.2 & 52.6 & -4.4 \\
\hline $\mathbf{L A}^{\mathrm{b}}$ & $7-\mathrm{SeB}_{10} \mathrm{H}_{10}^{2-}$ & & & & & & 0.0 & 0.0 & 0.0 & 0.0 \\
\hline LB & $2-\mathrm{SeB}_{10} \mathrm{H}_{10}^{2-}$ & & & 1 & & & 40.7 & 40.7 & 40.7 & 0.0 \\
\hline МА & 7,9- $\mathrm{Se}_{2} \mathrm{~B}_{9} \mathrm{H}_{9}$ & & & & & & 0.0 & 0.0 & 0.0 & 0.0 \\
\hline $\mathbf{M B}^{\mathrm{a}}$ & $7,8-\mathrm{Se}_{2} \mathrm{~B}_{9} \mathrm{H}_{9}$ & & & & & 1 & 35.1 & 35.1 & 35.1 & 0.0 \\
\hline
\end{tabular}

${ }^{a}$ Experimentally known isomers

${ }^{\mathrm{b}}$ Cyclopentadienyl metal derivatives are experimentally known

Table 6 Estimated energy penalties $\left(E_{\text {inc }}{ }^{\prime}\right)$, estimated relative energies $\left(E_{\text {inc }}^{\text {rel }}\right)$ for selenacarbaboranes and -borates. DFT computed relative energies are also reported for some structures. All values are in kcal mol $\mathrm{mol}^{-1}$

\begin{tabular}{|c|c|c|c|c|c|c|c|c|c|c|c|c|c|}
\hline & Compound & $\mu-H-$ & $\begin{array}{l}\mathrm{C}_{5 \mathrm{k}} \\
28.0\end{array}$ & $\begin{array}{l}\mathrm{C}(\mathrm{H}) \\
2.1\end{array}$ & $\begin{array}{l}\text { CC } \\
17.0\end{array}$ & $\begin{array}{l}\operatorname{Se}_{5 \mathrm{k}}(1)^{\prime} \\
48.2\end{array}$ & $\begin{array}{l}\mathrm{Se}_{5 \mathrm{k}}(2)^{\prime} \\
40.7\end{array}$ & $\begin{array}{l}\mathrm{Se}(\mathrm{H})^{\prime} \\
6.1\end{array}$ & $\begin{array}{l}\mathrm{SeC}^{\prime} \\
30.3\end{array}$ & $\sum E_{\mathrm{inc}}{ }^{\prime}$ & $E_{\text {inc }}^{\mathrm{rel}}$ & $E_{\text {calc }}$ & $\Delta E^{\prime}$ \\
\hline $\mathbf{N A}^{\mathrm{a}}$ & 7,9-SeCB ${ }_{9} \mathrm{H}_{11}$ & 10,11 & & 1 & & & & 1 & & 8.2 & 0.0 & 0.0 & 0 . \\
\hline $\mathbf{N B}^{\mathrm{b}}$ & $7,8-\mathrm{SeCB}_{9} \mathrm{H}_{11}$ & 9,10 & & 1 & & & & & 1 & 32.4 & 24.2 & 24.8 & -0.6 \\
\hline NC & $7,8-\mathrm{SeCB}_{9} \mathrm{H}_{11}$ & 10,11 & & & & & & 1 & 1 & 36.4 & 28.2 & 26.5 & 1.7 \\
\hline ND & $1,7-\mathrm{SeCB}_{9} \mathrm{H}_{11}$ & 9,10 & & 1 & & & 1 & & & 42.8 & 34.6 & 32.8 & 1.8 \\
\hline NE & $1,7-\mathrm{SeCB}_{9} \mathrm{H}_{11}$ & 8,9 & & 1 & & 1 & & & & 50.3 & 42.1 & 46.7 & -4.6 \\
\hline NF & $2,4-\mathrm{SeCB}_{9} \mathrm{H}_{11}$ & 9,10 & 1 & 1 & & & 1 & & & 70.8 & 62.6 & 65.0 & -2.4 \\
\hline $\mathbf{O A}$ & 7,9-SeCB ${ }_{9} \mathrm{H}_{10}^{-}$ & & & & & & & & & 0.0 & 0.0 & 0.0 & 0.0 \\
\hline OB & $7,8-\mathrm{SeCB}_{9} \mathrm{H}_{10}^{-}$ & & & & & & & & 1 & 30.3 & 30.3 & 30.3 & 0.0 \\
\hline OC & $7,1-\mathrm{SeCB}_{9} \mathrm{H}_{10}^{-}$ & & 1 & & & & & & & 28.0 & 28.0 & 32.6 & -4.6 \\
\hline $\mathbf{P A}^{\mathrm{c}}$ & $7,9,10-\mathrm{SeC}_{2} \mathrm{~B}_{8} \mathrm{H}_{10}$ & & & & 1 & & & & & 17.0 & 0.0 & 0.0 & \\
\hline PB & $7,8,10-\mathrm{SeC}_{2} \mathrm{~B}_{8} \mathrm{H}_{10}$ & & & & & & & & 1 & 30.3 & 13.3 & 2.5 & 9.8 \\
\hline PC & $7,1,9-\mathrm{SeC}_{2} \mathrm{~B}_{8} \mathrm{H}_{10}$ & & 1 & & & & & & & 28.0 & 11.0 & 7.6 & 3.4 \\
\hline PD & $7,8,9-\mathrm{SeC}_{2} \mathrm{~B}_{8} \mathrm{H}_{10}$ & & & & 1 & & & & 1 & 47.3 & 30.3 & 22.5 & 8.8 \\
\hline PE & $7,8,11-\mathrm{SeC}_{2} \mathrm{~B}_{8} \mathrm{H}_{10}$ & & & & & & & & 2 & 60.6 & 42.6 & 37.4 & 5.2 \\
\hline
\end{tabular}

${ }^{\text {a }}$ Strong candidate

${ }^{\mathrm{b}}$ 7-Cycloheanamine derivative is experimentally known

${ }^{\mathrm{c}}$ Experimentally known isomer

energy than the former and its phenyl derivative i.e., nido-7- $\mathrm{Ph}-7,9-\mathrm{PSB}_{9} \mathrm{H}_{9}$ was experimentally characterized [3].

\section{Selena (carba)boranes and-borates}

Estimated energy penalties were used to give the relative stability order of 25 selena(carba)boranes and -borates (Tables 5 and 6). The relative stability order is correctly reproduced in most cases, yet $\Delta \mathrm{E}^{\prime}$ (the difference of $E_{\text {inc }}^{\text {rel }}$ and $E_{\text {calc }}$ ) is larger for $\mathrm{SeC}_{2} \mathrm{~B}_{8} \mathrm{H}_{10}$ isomers (up to $9.8 \mathrm{kcal}$ $\mathrm{mol}^{-1}$ for PB).

The most stable $\mathrm{SeB}_{10} \mathrm{H}_{12}$ isomer i.e., nido-7$\mathrm{SeB}_{10} \mathrm{H}_{12}$ (JA) [39] has the selenium atom at vertex number seven with hydrogens bridging between $8 / 9$ and 10/11 positions (structural feature $\mathrm{Se}(\mathrm{H})$ twice). The increment system suggests the deprotonated species, i.e., nido-7-[ $\left.\mathrm{SeB}_{10} \mathrm{H}_{11}\right]^{-}$[35-41], with a hydrogen bridging positions 9/10 (KA) rather than positions 8/9 (KB) to be the most stable as in the case of exo-substituted
nido-7-[(PH) $\left.\mathrm{B}_{10} \mathrm{H}_{12}\right]^{-}[59]$. nido-7-[SeB $\left.{ }_{10} \mathrm{H}_{10}\right]^{2-}(\mathbf{L A})$ was reported as a ligand in complexes with different metal fragments [35-38, 42, 43, 71, 72]. The geometry of nido$7,8-\mathrm{Se}_{2} \mathrm{~B}_{9} \mathrm{H}_{9}$ (MB) [73-76] unlike that of nido-7,8$\mathrm{S}_{2} \mathrm{~B}_{9} \mathrm{H}_{9}$ could successfully be optimized and is $35.1 \mathrm{kcal}$ $\mathrm{mol}^{-1}$ higher in energy than the experimentally still unknown but energetically more favorable 7,9-isomer (MA). Similarly, the heteroatom apart nido-7,9$\mathrm{SeCB}_{9} \mathrm{H}_{11}$ (NA), the most stable $\mathrm{SeCB}_{9} \mathrm{H}_{11}$ isomer, is

Table 7 Estimated energy penalties $\left(E_{\text {inc }}{ }^{\prime}\right)$, estimated relative energies $\left(E_{\text {inc }}^{\text {rel'}}\right)$ for selenathiaboranes. All values are in $\mathrm{kcal} \mathrm{mol}^{-1}$

\begin{tabular}{llllll}
\hline & Compound & $E_{\text {inc }}^{\text {rel, }}$ & $E_{\text {calc }}$ & $\Delta E$ & Structural feature \\
\hline & $7,9-\mathrm{SeSB}_{9} \mathrm{H}_{9}$ & 0.0 & 0.0 & 0.0 & None \\
QB & $7,8-\mathrm{SeSB}_{9} \mathrm{H}_{9}$ & 40.2 & 40.2 & 0.0 & $\mathrm{SSe}^{\prime}$ \\
QC & $2,9-\mathrm{SeSB}_{9} \mathrm{H}_{9}$ & 40.7 & 36.0 & 4.7 & $\mathrm{Se}_{5 \mathrm{k}}(2)^{\prime}$ \\
QD & $9,2-\mathrm{SeSB}_{9} \mathrm{H}_{9}$ & 43.8 & 38.3 & 5.5 & $\mathrm{~S}_{5 \mathrm{k}}(2)^{\prime}$ \\
QE & $1,7-\mathrm{SeSB}_{9} \mathrm{H}_{9}$ & 48.1 & 51.9 & -3.8 & $\mathrm{Se}_{5 \mathrm{k}}(1)^{\prime}$ \\
QF & $7,1-\mathrm{SeSB}_{9} \mathrm{H}_{9}$ & 52.2 & 54.7 & -2.5 & $\mathrm{~S}_{5 \mathrm{k}}(1)^{\prime}$ \\
\hline
\end{tabular}


Table 8 Estimated relative energies $\left(\mathrm{kcal} \mathrm{mol}^{-1}\right)$ of 7,9,10-, 7,8,10-, 7,8,9- and 7,8,11-isomers in $\left[\mathrm{HetC}_{2} \mathrm{~B}_{8} \mathrm{H}_{10}\right]^{(4-\mathrm{n})-\mathrm{a}, \mathrm{b}}$

\begin{tabular}{|c|c|c|c|c|}
\hline $\begin{array}{l}\text { Heteroatom } \\
\text { (cluster charge) }\end{array}$ & ( & 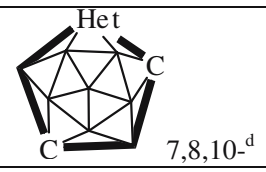 & $\sim_{\mathrm{C}} 7,8,9^{-}{ }^{\mathrm{e}}$ & $7,8,11^{-\mathrm{f}}$ \\
\hline $\begin{array}{l}\text { Het }=\mathrm{H}-\mathrm{Si} \\
(-1)\end{array}$ & $\begin{array}{l}\mathrm{CC}=17.0 \\
E_{\text {rel }}=7.5\end{array}$ & $\begin{array}{l}\mathrm{SiC}=8.5 \\
E_{\text {rel }}=0.0\end{array}$ & $\begin{array}{l}\mathrm{SiC}+\mathrm{CC}=25.5 \\
E_{\mathrm{rel}}=17.0\end{array}$ & $\begin{array}{l}2 * \mathrm{SiC}=17.0 \\
E_{\mathrm{rel}}=8.5\end{array}$ \\
\hline $\begin{array}{l}\text { Het }=\mathrm{H}-\mathrm{Ge} \\
(-1)\end{array}$ & $\begin{array}{l}\mathrm{CC}=17.0 \\
E_{\mathrm{rel}}=9.3\end{array}$ & $\begin{array}{l}\mathrm{GeC}=7.7 \\
E_{\text {rel }}=0.0\end{array}$ & $\begin{array}{l}\mathrm{GeC}+\mathrm{CC}=24.7 \\
E_{\mathrm{rel}}=17.0\end{array}$ & $\begin{array}{l}2 * \mathrm{GeC}=15.4 \\
E_{\mathrm{rel}}=7.7\end{array}$ \\
\hline $\begin{array}{l}\text { Het }=\text { H-Sn } \\
(-1)\end{array}$ & $\begin{array}{l}\mathrm{CC}=17.0 \\
E_{\mathrm{rel}}=14.6\end{array}$ & $\begin{array}{l}\mathrm{SnC}=2.4 \\
E_{\mathrm{rel}}=0.0\end{array}$ & $\begin{array}{l}\mathrm{SnC}+\mathrm{CC}=19.4 \\
E_{\mathrm{rel}}=17.0\end{array}$ & $\begin{array}{l}2 * \mathrm{SnC}=4.8 \\
E_{\mathrm{rel}}=2.4\end{array}$ \\
\hline $\begin{array}{l}\text { Het }=N \\
(-1)\end{array}$ & $\begin{array}{l}\mathrm{CC}=17.0 \\
E_{\mathrm{rel}}=0.0(0.0)\end{array}$ & $\begin{array}{l}\mathrm{NC}=28.4 \\
E_{\mathrm{rel}}=11.4(6.1)\end{array}$ & $\begin{array}{l}\mathrm{NC}+\mathrm{CC}=40.0 \\
E_{\mathrm{rel}}=23.0\end{array}$ & $\begin{array}{l}2 * \mathrm{NC}=56.8 \\
E_{\mathrm{rel}}=39.8\end{array}$ \\
\hline $\begin{array}{l}\text { Het }=\text { P } \\
(-1)\end{array}$ & $\begin{array}{l}\mathrm{CC}=17.0 \\
E_{\mathrm{rel}}=1.9(3.0)\end{array}$ & $\begin{array}{l}\mathrm{PC}=15.1 \\
E_{\mathrm{rel}}=0.0(0.0)\end{array}$ & $\begin{array}{l}\mathrm{PC}+\mathrm{CC}=32.1 \\
E_{\text {rel }}=17.0(17.9)\end{array}$ & $\begin{array}{l}2 * \mathrm{PC}=31.2 \\
E_{\text {rel }}=15.1(18.1)\end{array}$ \\
\hline $\begin{array}{l}\text { Het }=\text { As } \\
(-1)\end{array}$ & $\begin{array}{l}\mathrm{CC}=17.0 \\
E_{\mathrm{rel}}=1.0\end{array}$ & $\begin{array}{l}\mathrm{AsC}=16.0 \\
E_{\text {rel }}=0.0\end{array}$ & $\begin{array}{l}\mathrm{AsC}+\mathrm{CC}=33.0 \\
E_{\mathrm{rel}}=17.0\end{array}$ & $\begin{array}{l}2 * \mathrm{AsC}=32.0 \\
E_{\mathrm{rel}}=16.0\end{array}$ \\
\hline $\begin{array}{l}\mathrm{Het}=\mathrm{Sb} \\
(-1)\end{array}$ & $\begin{array}{l}\mathrm{CC}=17.0 \\
E_{\mathrm{rel}}=1.3\end{array}$ & $\begin{array}{l}\mathrm{SbC}=15.7 \\
E_{\mathrm{rel}}=0.0\end{array}$ & $\begin{array}{l}\mathrm{SbC}+\mathrm{CC}=32.7 \\
E_{\mathrm{rel}}=17.0\end{array}$ & $\begin{array}{l}2 * \mathrm{SbC}=31.4 \\
E_{\mathrm{rel}}=15.7\end{array}$ \\
\hline $\begin{array}{l}\text { Het }=\mathrm{H}-\mathrm{N} \\
\text { (0) }\end{array}$ & $\begin{array}{l}\mathrm{CC}=17.0 \\
E_{\text {rel }}=0.0(0.0)\end{array}$ & $\begin{array}{l}\mathrm{N}^{\mathrm{R}} \mathrm{C}=37.2 \\
E_{\text {rel }}=20.2(18.8)\end{array}$ & $\begin{array}{l}\mathrm{N}^{\mathrm{R}} \mathrm{C}+\mathrm{CC}=44.2 \\
E_{\mathrm{rel}}=37.2(41.3)\end{array}$ & $\begin{array}{l}2^{*} \mathrm{~N}^{\mathrm{R}} \mathrm{C}=74.4 \\
E_{\mathrm{rel}}=57.4(58.8)\end{array}$ \\
\hline $\begin{array}{l}\text { Het }=\text { H-P } \\
\text { (0) }\end{array}$ & $\begin{array}{l}\mathrm{CC}=17.0 \\
E_{\mathrm{rel}}=0.0(0.0)\end{array}$ & $\begin{array}{l}\mathrm{P}^{\mathrm{R}} \mathrm{C}=24.3 \\
E_{\text {rel }}=7.3(5.2)\end{array}$ & $\begin{array}{l}\mathrm{P}^{\mathrm{R}} \mathrm{C}+\mathrm{CC}=43.6 \\
E_{\text {rel }}=23.6(24.9)\end{array}$ & $\begin{array}{l}2 * \mathrm{P}^{\mathrm{R}} \mathrm{C}=48.6 \\
E_{\text {rel }}=31.6(29.5)\end{array}$ \\
\hline $\begin{array}{l}\text { Het }=\mathrm{H}-\mathrm{As} \\
(0)\end{array}$ & $\begin{aligned} \mathrm{CC} & =17.0 \\
E_{\mathrm{rel}} & =0.0\end{aligned}$ & $\begin{array}{l}\mathrm{As}^{\mathrm{R}} \mathrm{C}=17.3 \\
E_{\mathrm{rel}}=0.3\end{array}$ & $\begin{array}{l}\mathrm{As}^{\mathrm{R}} \mathrm{C}+\mathrm{CC}=34.3 \\
E_{\mathrm{rel}}=17.3\end{array}$ & $\begin{array}{l}2 * \mathrm{As}^{\mathrm{R}} \mathrm{C}=34.6 \\
E_{\mathrm{rel}}=17.6\end{array}$ \\
\hline $\begin{array}{l}\mathrm{Het}=\mathrm{H}-\mathrm{Sb} \\
(0)\end{array}$ & $\begin{aligned} \mathrm{CC} & =17.0 \\
E_{\mathrm{rel}} & =4.5\end{aligned}$ & $\begin{array}{l}\mathrm{Sb}^{\mathrm{R}} \mathrm{C}=12.5 \\
E_{\text {rel }}=0.0\end{array}$ & $\begin{array}{l}\mathrm{Sb}^{\mathrm{R}} \mathrm{C}+\mathrm{CC}=29.5 \\
E_{\mathrm{rel}}=17.0\end{array}$ & $\begin{array}{l}2 * \mathrm{Sb}^{\mathrm{R}} \mathrm{C}=25.0 \\
E_{\text {rel }}=12.5\end{array}$ \\
\hline $\begin{array}{l}\text { Het }=S \\
(0)\end{array}$ & $\begin{array}{l}\mathrm{CC}=17.0 \\
E_{\mathrm{rel}}=0(0.0)\end{array}$ & $\begin{array}{l}\mathrm{SC}=32.0 \\
E_{\text {rel }}=15.0(13.1)\end{array}$ & $\begin{array}{l}\mathrm{SC}+\mathrm{CC}=49.0 \\
E_{\mathrm{rel}}=32.0(32.9)\end{array}$ & $\begin{array}{l}2 * \mathrm{SC}=64.0 \\
E_{\mathrm{rel}}=47.0(48.8)\end{array}$ \\
\hline $\begin{array}{l}\text { Het }=\mathrm{Se} \\
(0)\end{array}$ & $\begin{array}{l}\mathrm{CC}=17.0 \\
E_{\text {rel }}=0(0.0)\end{array}$ & $\begin{array}{l}\mathrm{SeC}=30.3 \\
E_{\mathrm{rel}}=12.7(2.5)\end{array}$ & $\begin{array}{l}\mathrm{SeC}+\mathrm{CC}=47.3 \\
E_{\mathrm{rel}}=30.3(22.5)\end{array}$ & $\begin{array}{l}2 * \mathrm{SeC}=60.6 \\
E_{\text {rel }}=43.6(37.4)\end{array}$ \\
\hline $\begin{array}{l}\text { Het }=\mathrm{Te} \\
(0)\end{array}$ & $\begin{array}{l}\mathrm{CC}=17.0 \\
E_{\text {rel }}=0\end{array}$ & $\begin{array}{l}\mathrm{TeC}=28.6 \\
E_{\text {rel }}=11.6\end{array}$ & $\begin{array}{l}\mathrm{TeC}+\mathrm{CC}=45.6 \\
E_{\text {rel }}=28.6\end{array}$ & $\begin{array}{l}2 * \mathrm{TeC}=57.2 \\
E_{\mathrm{rel}}=40.2\end{array}$ \\
\hline
\end{tabular}

${ }^{\mathrm{a}}$ Het may be a three- or four-electron-donating heteroatom. $n$ corresponds to the number of electrons donated by a given heteroatom ${ }^{\mathrm{b}} \mathrm{B} 3 \mathrm{LYP} / 6-311+\mathrm{G}(\mathrm{d}, \mathrm{p}) / / \mathrm{B} 3 \mathrm{LYP} / 6-31 \mathrm{G}(\mathrm{d})+\mathrm{ZPE}$ computed relative stabilities of various $\left[\mathrm{HetC}_{2} \mathrm{~B}_{8} \mathrm{H}_{10}\right]^{(4-n)-}$ isomers are listed in parenthesis for various heteroatoms. These values are usually very close to the values predicted by estimated energy penalties ${ }^{\mathrm{c}} 7,9,10-\left[\mathrm{NC}_{2} \mathrm{~B}_{8} \mathrm{H}_{10}\right]^{-}, 7,9,10-(\mathrm{HN}) \mathrm{C}_{2} \mathrm{~B}_{8} \mathrm{H}_{10}, 7,9,10-\mathrm{SC}_{2} \mathrm{~B}_{8} \mathrm{H}_{10}, 7,9,10-\mathrm{SeC}_{2} \mathrm{~B}_{8} \mathrm{H}_{10}$ are experimentally known

$\mathrm{d} 7,8,10-\mathrm{SC}_{2} \mathrm{~B}_{8} \mathrm{H}_{10}$ is experimentally known

e 7,8,9-[ $\left[\mathrm{NC}_{2} \mathrm{~B}_{8} \mathrm{H}_{10}\right]^{-}$and 7-Me and 7-Ph derivatives of 7,8,9-(HP) $\mathrm{C}_{2} \mathrm{~B}_{8} \mathrm{H}_{10}$ are experimentally known

${ }^{\mathrm{f}} 7$ - $\mathrm{Ph}$ derivatives of 7,8,11-(HP) $\mathrm{C}_{2} \mathrm{~B}_{8} \mathrm{H}_{10}$ is experimentally known

still experimentally unknown although the 7-cyclohexanamine derivative of the 7,8-isomer (NB) is experimentally known [77]. nido-7,9,10- $\mathrm{SeC}_{2} \mathrm{~B}_{8} \mathrm{H}_{10}$ (PA) is experimentally known [73] and other computed $\mathrm{SeC}_{2} \mathrm{~B}_{8} \mathrm{H}_{10}$ structures (PB-PE) are thermodynamically less stable (Table 6).

\section{Selenathiaboranes}

The energy penalty $\left(40.2 \mathrm{kcal} \mathrm{mol}^{-1}\right)$ for the structural feature SSe was obtained as the energy difference of 7,8- and $7,9-\mathrm{SeSB}_{9} \mathrm{H}_{9}$. The latter is more stable and is 
experimentally known [69]. Relative energies of five $\mathrm{SeSB}_{9} \mathrm{H}_{9}$ isomers are given in Table 7.

Estimated energy penalties $\left(E_{\text {inc }}{ }^{\prime}\right)$ and corresponding estimated relative stabilities ( $E_{\text {inc }}^{\text {rel }}$ ) for other 11-vertex nido-hetero(carba)boranes and-borates

Estimated energy penalties for sila-, germa-, stanna-, bare and exo-substituted arsa- and stiba(carba)boranes and -borates are reported in Table 1, which can be used to produce the $E_{\text {inc }}^{\text {rel' }}$ for the 11-vertex nido-hetero(carba)boranes and -borates with $\mathrm{H}-\mathrm{Si}, \mathrm{H}-\mathrm{Ge}, \mathrm{H}-\mathrm{Sn}, \mathrm{As}$, $\mathrm{H}-\mathrm{As}, \mathrm{Sb}$ and $\mathrm{H}-\mathrm{Sb}$ heterogroups, respectively.

Prediction of thermodynamically most stable mixed heteroboranes and -borates with three open face heteroatoms

Energy penalties for the HetHet' structural features describe the relative energies of open-face heteroboranes with two equal heteroatoms, for example, $\left[\mathrm{C}_{2} \mathrm{~B}_{9} \mathrm{H}_{11}\right]^{2-}$ [57], $\mathrm{P}_{2} \mathrm{~B}_{9} \mathrm{H}_{11}$ [59], $\mathrm{Se}_{2} \mathrm{~B}_{9} \mathrm{H}_{9}$ or that of heteroboranes with two different heteroatoms, e.g., 7,8- and 7,9-isomers of $\left[\mathrm{PSB}_{9} \mathrm{H}_{9}\right]^{-}$and $\mathrm{PSB}_{9} \mathrm{H}_{10}, \mathrm{SeSB}_{9} \mathrm{H}_{9}$ etc. However, it is complex to predict the thermodynamically most stable isomer in mixed heteroboranes with three open-face heteroatoms, e.g., $\left[\mathrm{P}_{2} \mathrm{CB}_{8} \mathrm{H}_{9}\right]^{-} \quad$ [78], [ $\left.\mathrm{PC}_{2} \mathrm{~B}_{8} \mathrm{H}_{10}\right]^{-}$[79, 80], $\mathrm{SC}_{2} \mathrm{~B}_{8} \mathrm{H}_{10}$ [3], $\mathrm{SeC}_{2} \mathrm{~B}_{8} \mathrm{H}_{10}$ [73], $\mathrm{NC}_{2} \mathrm{~B}_{8} \mathrm{H}_{11}$ [81], [ $\left.\mathrm{NC}_{2} \mathrm{~B}_{8} \mathrm{H}_{10}\right]^{-}$[81]. Here we present only $\left[\mathrm{HetC}_{2} \mathrm{~B}_{8} \mathrm{H}_{10}\right]^{(4-\mathrm{n})-}$ examples, (where $n=$ number of electrons donated by a heterogroup, and Het may be a three-electron-donating heteroatom/group, i.e., $\mathrm{H}-\mathrm{C}$, $\mathrm{H}-\mathrm{Si}, \mathrm{H}-\mathrm{Ge}, \mathrm{H}-\mathrm{Sn}, \mathrm{N}, \mathrm{P}, \mathrm{As}, \mathrm{Sb}$, or a four-electrondonating heteroatom/group, i.e., $\mathrm{H}-\mathrm{N}, \mathrm{H}-\mathrm{P}, \mathrm{H}-\mathrm{As}, \mathrm{H}-$ $\mathrm{Sb}, \mathrm{S}, \mathrm{Se}, \mathrm{Te}$ (Table 8). All four possibilities for $\left[\mathrm{HetC}_{2} \mathrm{~B}_{8} \mathrm{H}_{10}\right]^{(4-\mathrm{n})-}$ structures with open face heteroatoms, i.e., 7,9,10-, 7,8,10-, 7,8,9- and 7,8,11$\left[\mathrm{HetC}_{2} \mathrm{~B}_{8} \mathrm{H}_{10}\right]^{(4-\mathrm{n})-}$ will be discussed.

Both 7,9,10- and 7,8,10-isomers of $\left[\mathrm{HetC}_{2} \mathrm{~B}_{8} \mathrm{H}_{10}\right]^{-}$ have one structural feature each, i.e., $\mathrm{CC}$ and $\mathrm{HetC}$, respectively. However, 7,8,9- and 7,8,11-isomers of $\left[\mathrm{HetC}_{2} \mathrm{~B}_{8} \mathrm{H}_{10}\right]^{-}$have two structural features each, i.e., $\mathrm{HetC}+\mathrm{CC}$ and $2 \cdot \mathrm{HetC}$, respectively. For group 14 heteroatoms, i.e., $\mathrm{H}-\mathrm{Si}, \mathrm{H}-\mathrm{Ge}$ and $\mathrm{H}-\mathrm{Sn}$, the $\mathrm{HetC}$, i.e., $\mathrm{SiC}, \mathrm{GeC}$ and $\mathrm{SnC}$ energy penalties are smaller than that of $\mathrm{CC}$ and therefore 7,8,10-isomers (i.e., isomers with the HetC structural feature) are more stable. The 7,8,11isomers with twice the structural feature HetC for threeelectron-donating group 14 heteroatoms is not a too high energy option. HetC is very small for group 14 heteroatoms and therefore the 7,8,11-isomers of $\mathrm{SnC}_{2} \mathrm{~B}_{8} \mathrm{H}_{10}$ is only $2.4 \mathrm{kcal} \mathrm{mol}^{-1}$ higher in energy than the 7,8,10-isomer (see Table 8). In the case of threeelectron-donating bare nitrogen atom $(\mathrm{N})$, however, the $\mathrm{NC}$ structural feature has a larger disfavoring effect than $\mathrm{CC}$, and therefore the 7,9,10-isomer (with structural feature CC) is more stable than the 7,8,10-isomer (with structural feature NC). But for other three-electrondonating group 15 heteroatoms, i.e., $\mathrm{P}, \mathrm{As}, \mathrm{Sb}$, HetC has less disfavoring effect than $\mathrm{CC}$ and therefore the 7,8,10isomer is more favorable for $\left[\mathrm{PC}_{2} \mathrm{~B}_{8} \mathrm{H}_{10}\right]^{-}$, $\left[\mathrm{AsC}_{2} \mathrm{~B}_{8} \mathrm{H}_{10}\right]^{-},\left[\mathrm{SbC}_{2} \mathrm{~B}_{8} \mathrm{H}_{10}\right]^{-}$.

The estimated relative stabilities for $\mathrm{HetC}_{2} \mathrm{~B}_{8} \mathrm{H}_{10}$ structures for four-electron-donating heteroatoms are listed in Table 8. $\mathrm{H}-\mathrm{N}$ and $\mathrm{H}-\mathrm{P}$ have HetC energy penalties $\left(E_{\mathrm{inc}}{ }^{\prime}\left[\mathrm{N}^{\mathrm{R}} \mathrm{C}\right]=36.0 \mathrm{kcal} \mathrm{mol}{ }^{-1}\right.$ and $E_{\mathrm{inc}}{ }^{\prime}\left[\mathrm{P}^{\mathrm{R}} \mathrm{C}\right]$ $\left.=23.6 \mathrm{kcal} \mathrm{mol}^{-1}\right)$ much larger than CC $\left(E_{\text {inc }}[\mathrm{CC}]\right.$ $=17.0 \mathrm{kcal} \mathrm{mol}{ }^{-1}$ ) and hence 7,9,10-isomers with structural feature $\mathrm{CC}$ are more favorable than the 7,8,10-isomers. For $\mathrm{H}-\mathrm{As}$, however, 7,8,10-AsC ${ }_{2} \mathrm{~B}_{8} \mathrm{H}_{11}$ (with structural feature $\mathrm{As}^{\mathrm{R}} \mathrm{C}\left(E_{\text {inc }}{ }^{\prime}\left[\mathrm{As}^{\mathrm{R}} \mathrm{C}\right]=17.3 \mathrm{kcal}\right.$ $\mathrm{mol}^{-1}$ ) and 7,9,10-AsC ${ }_{2} \mathrm{~B}_{8} \mathrm{H}_{11}$ with the structural feature CC $\left(E_{\text {inc }}{ }^{\prime}[C C]=17.0 \mathrm{kcal} \mathrm{mol}^{-1}\right)$ are very similar in energy. Since HetHet' energy penalties decrease down the group, the HetC energy penalty $\left(\mathrm{Sb}^{\mathrm{R}} \mathrm{C}\right)$ for a fourelectron-donating antimony atom $\left(\mathrm{Sb}^{\mathrm{R}} \mathrm{C}\right)$ is $4.8 \mathrm{kcal}$ $\mathrm{mol}^{-1}$ less than that of $\mathrm{As}^{\mathrm{R}} \mathrm{C}$ and therefore the 7,8,10isomer is more stable for ( $\mathrm{HSb}) \mathrm{C}_{2} \mathrm{~B}_{8} \mathrm{H}_{10}$ as compared to the 7,9,10-isomer (7,9,10-isomer has structural feature $\mathrm{CC}$ and $E_{\text {inc }}{ }^{\prime}[\mathrm{CC}]>E_{\text {inc }}{ }^{\prime}\left[\mathrm{Sb}^{\mathrm{R}} \mathrm{C}\right]$.

HetC energy penalties for all four-electron-donating group 16 heteroatoms are much higher than $\mathrm{CC}$ and therefore $7,9,10-\mathrm{HetC}_{2} \mathrm{~B}_{8} \mathrm{H}_{10}$ isomers are thermodynamically more stable than 7,8,10-isomers. 7,8,9- and $7,8,11$-isomers have more than one structural feature, i.e., HetHet $+\mathrm{HetC}$ and $2 \cdot \mathrm{HetC}$, respectively, and therefore have even larger disfavoring effects for fourelectron-donating heteroatoms.

\section{Conclusions}

Estimated energy penalties present a convenient method to predict the relative stabilities of 11-vertex nido-heteroboranes and -borates. Energy penalties for adjacent heteroatoms increase along the period and decrease down the group. Four-electron-donating heteroatoms generally have larger energy penalties than those of three-electron-donating heteroatoms. Larger heteroatoms usually have larger $\operatorname{Het}_{5 \mathrm{k}}(1)$ and $\mathrm{Het}_{5 \mathrm{k}}(2)$ energy penalties and smaller HetHet' energy penalties, indicating that they prefer open-face vertices and that the destabilizing effect of adjacent heteroatoms is smaller for larger heteroatoms. Most stable mixed heteroboranes with more than two open-face heteroatoms have different but easily predictable heteroatom positions in the thermodynamically most stable 11-vertex nido-heteroborane isomers. Energy penalties are likely to have periodic trends in other polyborane clusters.

\section{Supplementary material}

Cartesian coordinates of the optimized geometries of 11-vertex nido-heterocarbaboranes and -borates considered in this paper are listed in Appendices I through V. 
Acknowledgement Financial support by DFG is gratefully acknowledged.

\section{References}

1. Štibr B (2002) Collec Czech Chem Commun and references therein 67:843-868

2. Haubold W, Keller W, Sawitzki G (1988) Angew Chem Int Ed Engl 27:925-926

3. Shedlow AM, Sneddon LG (1998) Inorg Chem 37:5269-5277

4. Todd LJ, Little JL, Silverstein HT (1969) Inorg Chem 8:16981703

5. Little JL, Whitesell MA, Chapman RW, Kester JG, Huffman JC, Todd LJ (1993) Inorg Chem 32:3369-3372

6. Williams RE (1992) Chem Rev and references therein 92:177207

7. Fox MA, Goeta AE, Hughes AK, Johnson AL (2002) J Chem Soc Dalton Trans 9:2009-2019

8. Fox MA, Greatrex R, Nikrahi A, Brain PT, Picton MJ, Rankin DWH, Robertson HE, Bühl M, Li L, Beaudet RA (1998) Inorg Chem 37:2166-2176

9. Dirk W, Paetzold P, Radacki K (2001) Z Anorg Allg Chem 627:2615-2618

10. Dopke JA, Bridges AN, Schmidt MR, Gaines DF (1996) Inorg Chem 35:7186-7187

11. Wesemann L, Englert U, Seyferth D (1995) Angew Chem 107:2345-2436

12. Wesemann L, Englert U, Seyferth D (1995) Angew Chem Int Ed Engl 34:2236-2238

13. Dopke JA, Powel DR, Hayashi RK, Gaines DF (1998) Inorg Chem 37:4160-4161

14. Loffredo RE, Norman AD (1971) J Am Chem Soc 93:55875588

15. Wesemann L, Trinkaus M, Ruck M (1999) Angew Chem Int Ed 38:2375-2377

16. Wesemann L, Ramjoie Y, Trinkaus M, Spaniol TP (1998) Eur J Inorg Chem 9:1263-1268

17. Wesemann L, Ramjoie Y, Trinkaus M, Ganter B (1997) Inorg Chem 36:5192-5197

18. Greenwood NN, Youll B (1975) J Chem Soc Dalton Trans 2:158-162

19. Dupont TJ, Loffredo RE, Haltiwanger RC, Turner CA, Norman AD, (1978) Inorg Chem 17:2062-2067

20. Loffredo RE, Dupont TJ, Haltiwanger RC, Norman AD (1977) J Chem Soc Chem Commun 4:121-122

21. Loffredo RE, Drullinger LF, Slater JA, Turner CA, Norman AD (1976) Inorg Chem 15:478-480

22. Todd LJ, Burke AR, Garber AR, Silverstein HT, Storhoff BN (1970) Inorg Chem 9:2175-2179

23. Bould J, Kennedy JD, Ferguson G, Tony DF, O'Riordan GM, Spalding TR (2003) Dalton Trans 23:4557-4564

24. O'Connell D, Patterson JC, Spalding TR, Ferguson G, Gallagher JF, Li Y, Kennedy JD, Macias R, Thornton-Pett M, Holub J (1996) J Chem Soc Dalton Trans 15:3323-3333

25. Fontaine XLR, Kennedy JD, McGrath M, Spalding TR (1991) Magn Reson Chem 29:711-720

26. Wright WF, Garber AR, Todd LJ (1978) J Magn Reson 30:595-602

27. Little JL, Pao SS (1978) Inorg Chem 17:584-587

28. Little JL, Pao SS, Sugathan KK (1974) Inorg Chem 13:17521756

29. Hanusa TP, Roig de Parisi N, Kester JG, Arafat A, Todd LJ (1987) Inorg Chem 26:4100-4102

30. Little JL (1979) Inorg Chem 18:1598-1600

31. Yamamoto T, Todd LJ (1974) J Organomet Chem 67:75-80

32. Colquhoun HM, Greenhough TJ, Wallbridge MGH (1979) J Chem Research 7:248

33. Valnot JY (1978) Synthesis 8:590-592

34. Pretzer WR, Rudolph RW (1976) J Am Chem Soc 98:14411447
35. Ferguson G, Gallagher JF, McGrath M, Sheehan JP, Spalding TR, Kennedy JD (1993) J Chem Soc Dalton Trans 1:27-34

36. Ferguson G, Parvez M, MacCurtain JA, Dhubhghaill ON, Spalding TR, Reed D (1987) J Chem Soc Dalton Trans 4:699 704

37. Little JL, Friesen GD, Todd LJ (1977) Inorg Chem 16:869-872

38. Faridoon, Dhubhghaill ON, Spalding TR, Ferguson G, Kaitner B, Fontaine XLR, Kennedy JD (1989) J Chem Soc Dalton Trans 9:1657-1668

39. Ferguson G, Hampden-Smith MJ, Dhubhghaill ON, Spalding TR (1988) Polyhedron 7:187-193

40. Barriola AM, Hanusa TP, Todd LJ (1980) Inorg Chem 19:2801-2802

41. Reed D, Ferguson G, Ruhl BL, Dhubhghaill ON, Spalding TR (1988) Polyhedron 7:17-23

42. Faridoon S, Trevor R, Ferguson G, Kennedy JD, Fontaine XLR (1989) J Chem Soc Chem Commun 14:906-908

43. Faridoon O, Dhubhghaill ON, Spalding TR, Ferguson G, Kaitner B, Fontaine XLR, Kennedy JD (1988) J Chem Soc Dalton Trans 11:2739-2745

44. Thornton-Pett M, Kennedy JD, Spalding F, Spalding TR (1995) Act Cryst C51:840-843

45. Ferguson G, O'Connell D, Spalding TR (1994) Act Cryst C50:1432-1434

46. Ferguson G, Gallagher JF, Sheehan JP, Spalding TR, Kennedy JD, Macias R (1993) J Chem Soc Dalton Trans 20:3147-3148

47. Sheehan JP, Spalding TR, Ferguson G, Gallagher JF, Kaitner B, Kennedy JD (1993) J Chem Soc Dalton Trans 1:35-42

48. Faridoon, McGrath M, Spalding TR, Fontaine XLR, Kennedy JD, Thornton-Pett M (1990) J Chem Soc Dalton Trans 6:18191829

49. Ferguson G, Lough AJ, Faridoon, McGrath MN, Spalding TR, Kennedy JD, Fontaine XLR (1990) J Chem Soc Dalton Trans 6:1831-1839

50. Ferguson G, Gallagher JF, Sheehan JP, Spalding TR (1998) J Organomet Chem 550:477-480

51. Ferguson G, Kennedy JD, Fontaine XLR, Faridoon, Spalding TR (1988) J Chem Soc Dalton Trans 10:2555-2564

52. Mceneaney PA, Spalding TR, Ferguson G (1997) J Chem Soc Dalton Trans 2:145-147

53. Ferguson G, Kennedy JD, Fontaine XLR, Faridoon, Spalding TR (1988) J Chem Soc Dalton Trans 10:2555-2564

54. Williams RE (1965) J Am Chem Soc 87:3513-3515

55. Williams RE (1970) Carboranes. In: Brotherton RJ, Steinberg $\mathrm{H}$ (eds) Progress in Boron Chemistry, Vol 2, Chapter 2. Pergamon Press, Oxford, England, p 57

56. Hofmann M, Fox MA, Greatrex R, Schleyer PvR, Williams RE (2001) Inorg Chem 40:1790-1801

57. Kiani FA, Hofmann M (2004) Inorg Chem 43:8561-8571

58. Kiani FA, Hofmann M (2005) Eur J Inorg Chem 12:25452553

59. Kiani FA, Hofmann M (2005) Inorg Chem 44:3746-3754

60. Frisch MJ, Trucks GW, Schlegel HB, Scuseria GE, Robb MA, Cheeseman JR, Zakrzewski VG, Montgomery JA, Stratmann RE, Burant JC, Dapprich S, Millam JM, Daniels AD, Kudin KN, Strain MC, Farkas O, Tomasi J, Barone V, Cossi M, Cammi R, Mennucci B, Pomelli C, Adamo C, Clifford S, Ochterski J, Petersson GA, Ayala PY, Cui Q, Morokuma K, Malick DK, Rabuck AD, Raghavachari K, Foresman JB, Cioslowski J, Ortiz JV, Stefanov BB, Liu G, Liashenko A, Piskorz P, Komaromi I, Gomperts R, Martin, RL, Fox DJ, Keith T, Al-Laham MA, Peng CY, Nanayakkara A, Gonzalez C, Challacombe M, Gill PMW, Johnson BG, Chen W, Wong MW, Andres JL, Head-Gordon M, Replogle ES, Pople JA (1998) Gaussian 98. Gaussian Inc, Pittsburgh, PA

61. Huzinaga S, Andzelm J (1984) Gaussian basis sets for molecular calculations. Elsevier, Amsterdam, pp 23-25

62. These values were optimized for the atomic ground state anion, using ROHF with a flexible ECP basis set, by Ted Packwood at NDSU. Diffuse functions for these and other heteroatoms may be found at the website: http://phoenix.liu.edu/ nmatsuna/ gamess/refs/basis.refs.html 
63. Clark T, Chandrasekhar J, Spitznagel GW, Schleyer PvR (1983) J Comput Chem 4:294-301

64. Kang SO, Carroll PJ, Sneddon LG (1989) Inorg Chem 28:961964

65. Kang SO, Carroll PJ, Sneddon LG (1988) Organometallics 7:772-776

66. Zimmerman GJ, Sneddon LG (1981) J Am Chem Soc 103:1102-1111

67. Thompson DA, Rudolph RW (1976) J Chem Soc Chem Commun 19:770-771

68. Kang SO, Sneddon LG (1988) Inorg Chem 27:3298-3300

69. Friesen GD, Barriola A, Daluga P, Ragatz P, Huffman JC, Todd LJ (1980) Inorg Chem 19:458-462

70. Holub J, Kennedy J D, Jelínek T, Stíbr B (1994) Inorg Chem $8: 1317-1323$

71. Ferguson G, Faridoon, Spalding TR (1988) Acta Cryst C44:1368-1371

72. Ferguson G, Ruhl BL, Ni DO, Spalding TR (1987) Acta Cryst C43:1250-1253
73. Base K, Štibr B (1977) Chem Ind 22:919-920

74. Friesen GD, Barriola A, Todd LJ (1978) Chem Ind 16:631

75. Base K (1983) Collect Czech Chem Commun 48:2593-2603

76. Schultz RV, Huffman JC, Todd LJ (1979) Inorg Chem 18:2883-2886

77. Arafat A, Friesen GD, Todd LJ (1983) Inorg Chem 22:37213724

78. Bakardjiev M, Holub J, Štíbr B, Hnyk D, Wrackmeyer B (2005) Inorg Chem DOI 10.1021/ic048232c

79. Stíbr B, Holub J, Bakardjiev M, Hnyk D, Tok OL, Milius W, Wrackmeyer B (2002) Eur J Inorg Chem 9:2320-2326

80. Holub J, Ormsby DL, Kennedy J D, Greatrex R, Stibr B (2000) Inorg Chem Commun 3:178-181

81. Plešek J, Stíbr B, Hnyk D, Jelínek T, Heřmánek S, Kennedy JD, Hofmann M, Schleyer PvR (1998) Inorg Chem 37:39023909 